\title{
Center for Mineral Resources: U.S. Geological Survey- University of Arizona, Department of Geosciences Porphyry Copper Deposit Life Cycles Field Conference, Southeastern Arizona, May 21-22, 2002
}

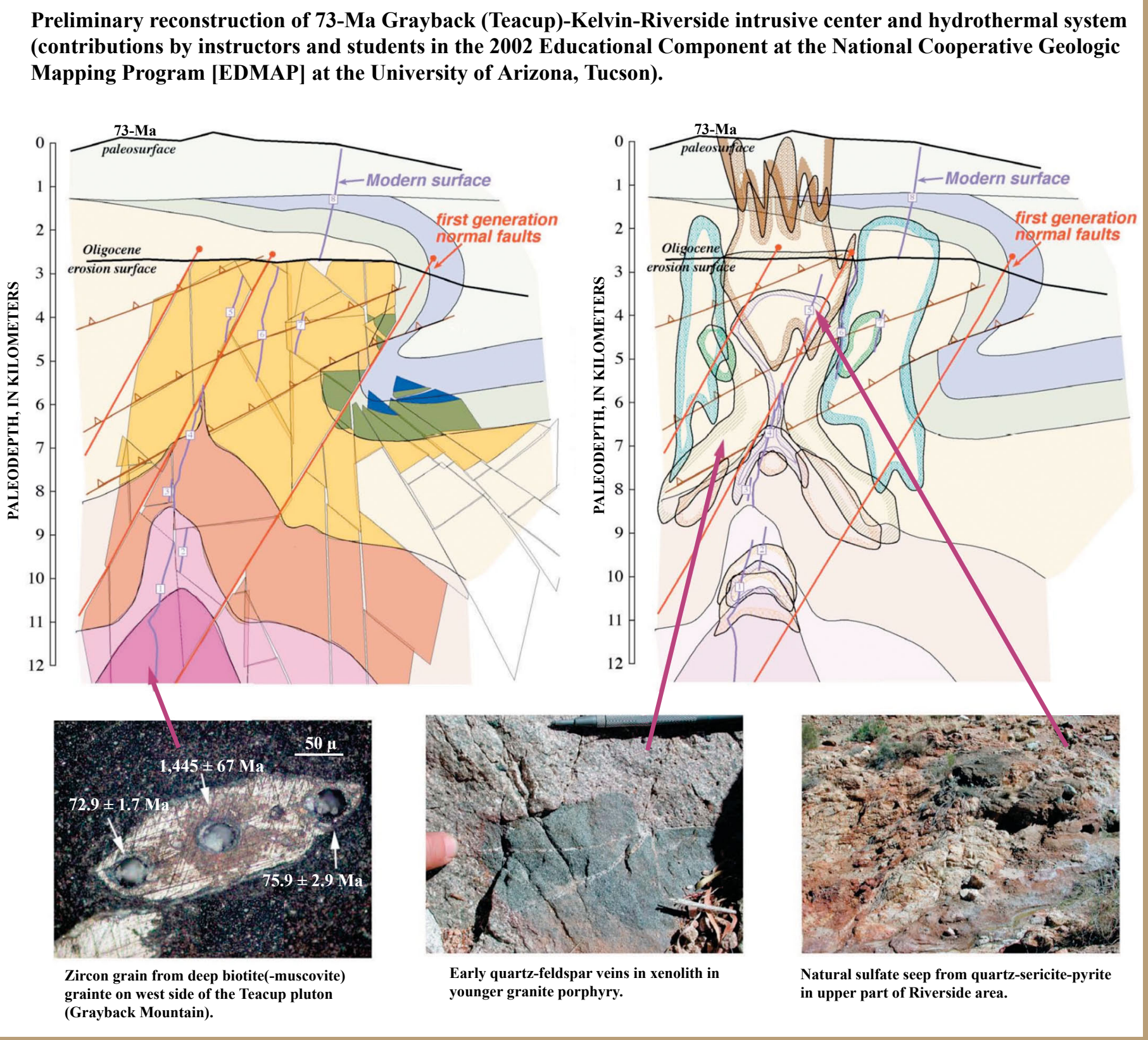

Scientific Investigations Report 2005-5020

U.S. Department of the Interior

U.S. Geological Survey 


\section{Center for Mineral Resources: U.S. Geological Survey- University of Arizona, Department of Geosciences Porphyry Copper Deposit Life Cycles Field Conference, Southeastern Arizona, May 21-22, 2002}

By Mark Barton, James Brown, Gordon Haxel, Timothy Hayes, Eric Jensen, David Johnson, Robert Kamilli, Keith Long, David Maher, and Eric Seedorff

Scientific Investigations Report 2005-5020 


\section{U.S. Department of the Interior \\ Gale A. Norton, Secretary}

\section{U.S. Geological Survey Charles G. Groat, Director}

\section{U.S. Geological Survey, Reston, Virginia: 2005}

For sale by U.S. Geological Survey Information Services Box 25286, Denver Federal Center

Denver, CO 80225

This report and any updates to it are available online at: http://pubs.usgs.gov/pp/pp1710/

For additional information write to:

U.S. Geological Survey

Box 25046, Mail Stop 421, Denver Federal Center

Denver, C0 80225-0046

Additional USGS publications can be found at: http://geology.usgs.gov/products.html

For more information about the USGS and its products: Telephone: 1-888-ASK-USGS (1-888-275-8747)

World Wide Web: http://www.usgs.gov/

Any use of trade, product, or firm names in this publication is for descriptive purposes only and does not imply endorsement of the U.S. Government.

Although this report is in the public domain, it contains copyrighted materials that are noted in the text. Permission to reproduce those items must be secured from the individual copyright owners.

Cataloging-in-publication data are on file with the Library of Congress (URL http://www.loc.gov/).

Produced in the Western Region, Menlo Park, California Manuscript approved for publication, February 3, 2005

Text edited by George A. Havach

Layout and design by Judy Weathers and Susan Mayfield 


\section{Workshop Organizers}

Mark D. Barton

University of Arizona

Department of Geosciences

Gould-Simpson \#339

P.O. Box 210077

Tucson, AZ 85721

Telephone: (520) 621-8529

E-mail:mdbarton@geo.arizona.edu

Robert J. Kamilli

U.S. Geological Survey

520 North Park Ave., Room 355

Tucson, AZ 85719

Telephone: (520) 670-5576

E-mail: bkamilli@usgs.gov

Eric Seedorff

University of Arizona

Department of Geosciences

Gould-Simpson \#316

P.0. Box 210077

Tucson, AZ 85721

Telephone: (520) 626-3921

E-mail: seedorff@geo.arizona.edu 


\section{Contents}

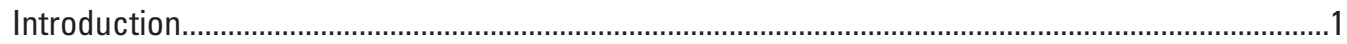

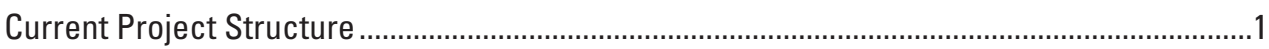

Task 1: Mesozoic and Cenozoic Crustal Framework........................................................

Task 2: Regional Distribution of Chemical Elements .......................................................

Task 3: Characteristics and Evolution of Hydrothermal Systems .....................................

Task 4: Dispersion and Concentration of Materials from Porphyry Copper and Related

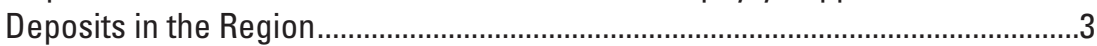

Task 5: Historical Life-Cycle Analysis of Porphyry Copper Exploration and Mining.........5

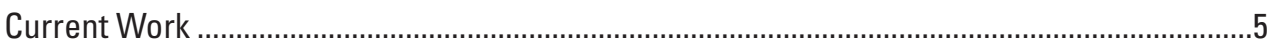

Day 1: Tucson to Globe, Ariz

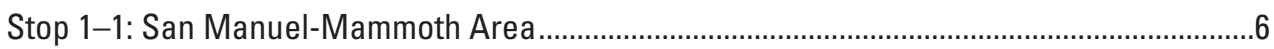

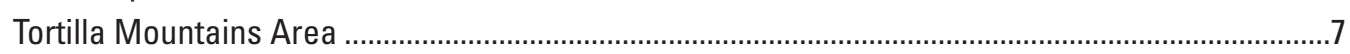

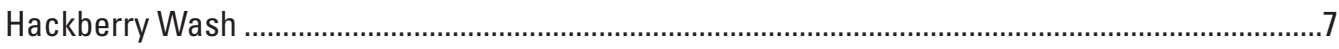

Stop 1-2: Middle of the Hackberry Wash Section ..................................................................

Stop 1-3: Base of the Hackberry Wash Section in Falls Canyon.................................................

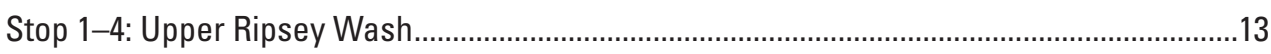

Grayback-Riverside Area ..............................................................................................................13

Stop 1-5: Radio Tower-Overlook of the Teacup Intrusive Center and Associated Hydrothermal Systems .............................................................................................13

Stop 1-6 (Optional): Zelleweger Wash—a Laramide Thrust Fault(?) in Ruin Granite .............16

Stop 1-7: Lower Ripsey Wash-Modern Natural Dispersion from Upper Parts of the Kelvin-Riverside Hydrothermal Center ......................................................................16

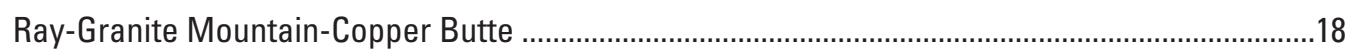

Stop 1-8: Overlook of the Ray Mine .................................................................................

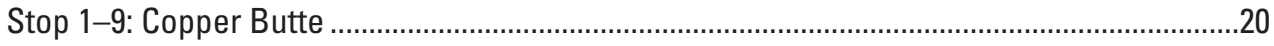

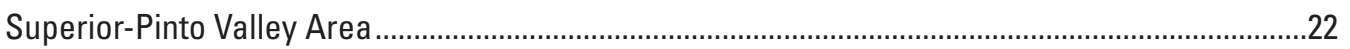

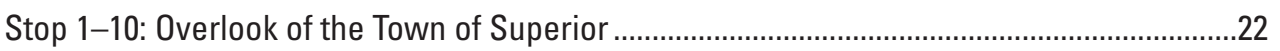

Stop 1-11: Overlook of the Pinto Valley Mine at the Exposure of Schultz Granite

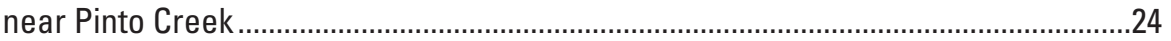

Day 2: Pinal Creek Basin near Globe, Ariz

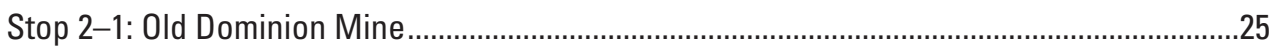

Stop 2-2: Overlook of the Valley from the Holiday Inn Express Parking Lot............................26

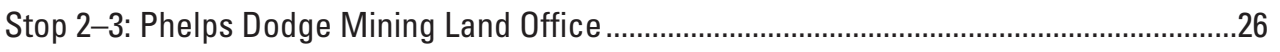

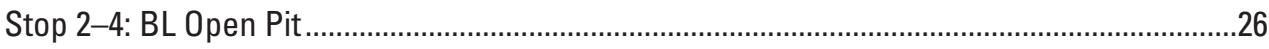

Stop 2-5: Willow Springs Solvent-Extraction Plant .................................................................

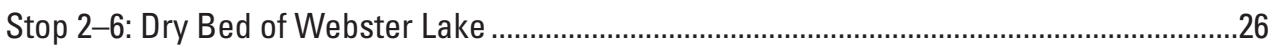

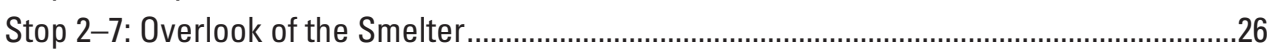

Stop 2-8 (Lunch Stop): Overlook of the Valley from the Edge of the Tailings Pile ..................26

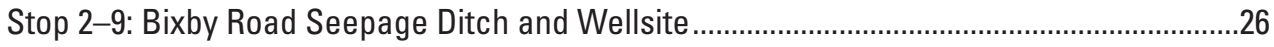

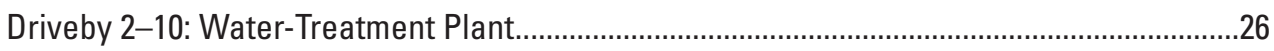

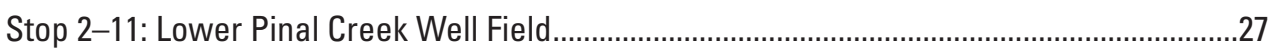

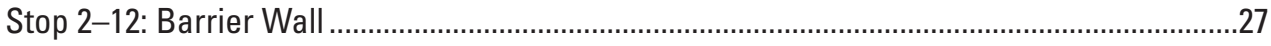

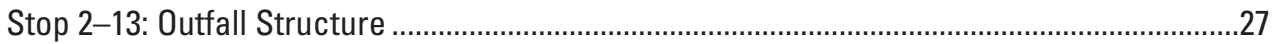


Driveby 2-14: H\&E Ranch Headquarters ................................................................................

Stop 2-15: Pinal Creek at the Pringle Well Field and Pump Station .......................................28

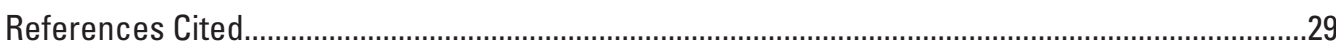

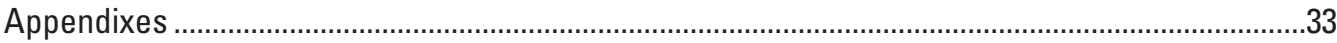

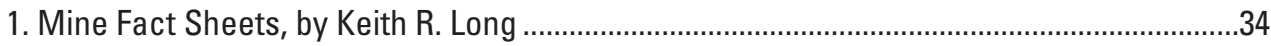

San Manuel Mine, Concentrator, and Smelter ………….................................................34

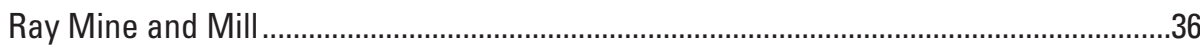

Pinto Valley Mine and Mill...........................................................................................38

2. Abstracts for Evening Talks and Posters During the Field Trip .........................................42

Historical Life-Cycle Analysis of Southwestern Porphyry Copper Mining, by Keith R. Long. .. .42

Abundance and Behavior of Ore Metals in Latest Cretaceous Through Early Tertiary ("Laramide") Metaluminous and Peraluminous Granitoids, South-Central Arizona and North-Central Sonora, Mexico, by Gordon B. Haxel. . .42

Evaluation and Application of the NURE Regional Geochemical Data for the Southwest: Nogales and Tucson $2^{\circ}$ Quadrangles, Southern Arizona, by Gordon B. Haxel .....43

\section{Figures}

1-1. Composite geologic map of the Tortilla-Dripping Spring-Pinal Mountains area, southeastern Arizona, showing the locations of towns, principal mineralized centers, and field-trip route

1-2. Map of the Arizona-New Mexico-Sonora, Mexico, region, showing the distribution of Laramide (Cretaceous and Triassic) igneous rocks and related hydrothermal systems and older rocks in porphyry copper province

1-3. Time-space diagram illustrating the evolution of magmatic-hydrothermal systems .

1-4. Schematic diagrams showing generalized mass flow in the crust, at the surface, and during mining in relation to project tasks.

1-5. Schematic map of the northern Tortilla Mountains, showing the locations of principal faults, unconformities, and some major intrusive centers.

1-6. Stratigraphic column and schematic cross section along measured section in Hackberry Wash, showing area of stops $1-2 a$ and $1-2 b$.

1-7. Geologic map of the northern Tortilla Mountains and adjacent valleys, showing the distribution of clast types in mid-Tertiary sedimentary rocks .

1-8. Sequential palinspastic reconstruction of mid-Tertiary faulting in the Hackberry/Ripsey Wash area

1-9. Schematic map of the northern Tortilla Mountains, showing generalized distribution of hydrothermal alteration, igneous rocks, principal faults, and field-trip stops...

1-10. Diagrams illustrating evolution of the principal Laramide magmatic, hydrothermal, and structural features in the northern Tortilla Mountains.

1-11. Modern geologic cross section and palinspastic reconstruction of the Grayback-KelvinRiverside area

1-12. Schematic cross section across the northern Tortilla Mountains...........................................20

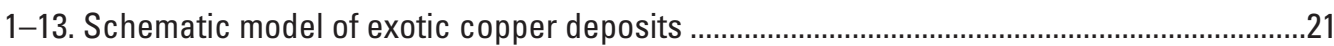


1-14. Plan view of the Magma Mine, showing geologic relations at the 3,600-ft level, distribution of materials along the Magma vein/replacement system, and the scale of the recently (1994) discovered, fully hidden, large, high-grade Resolution (Magma) porphyry copper deposit.......23

2-1. Generalized map of the Pinal Creek basin near Globe, Ariz. .25

2-2. Cross section of aquifer at the Bixby Road seepage ditch near Globe, Ariz............................27

2-3. Plots of water level, Fe content, and pH from 1985 to 2002 in well 101 at the Bixby Road seepage ditch

2-4. Photographs of Pinal Creek, about $4.5 \mathrm{~km}$ upstream from the Pringle Pump Station near Globe, Ariz., showing patterns of growth and partial removal of vegetation since 1993 


\title{
Center for Mineral Resources: U.S. Geological Survey- University of Arizona, Department of Geosciences Porphyry Copper Deposit Life Cycles Field Conference, Southeastern Arizona, May 21-22, 2002
}

\author{
By Mark Barton, ${ }^{1}$ James Brown, ${ }^{2}$ Gordon Haxel, ${ }^{3}$ Timothy Hayes, ${ }^{4}$ Eric Jensen, ${ }^{1}$ David Johnson, Robert Kamilli, \\ Keith Long, ${ }^{4}$ David Maher, ${ }^{1}$ and Eric Seedorff ${ }^{1}$
}

\section{Introduction}

Fiscal year 2002 was the first feasibility-study year of a U.S. Geological Survey (USGS)-University of Arizona (Center for Mineral Resources) joint project, titled "Porphyry Copper Deposit Life Cycles-a Regional Approach.” Early results, progress, and some planning from the project work to date were illustrated at sites in the Tortilla-Dripping SpringPinal Mountains area during the field conference (fig. 1-1). We also visited the study sites of scientists of the USGS Water Resources Discipline, who have been working in the MiamiGlobe area for more than a decade.

The purpose of this field conference was threefold. The first purpose was to share among the participants our research and thinking since the official start of the project on October 1, 2001. The first day emphasized the genesis of porphyry copper deposits and their geologic context; the second day focused more on the effects, both local and regional, of mining and processing. The second purpose was to increase collaboration among parties in academia, the USGS, and the mining industry, as well as other stakeholders. The third, and most important, purpose was to obtain suggestions and advice from all participants in order to aid in creating a continuing proposal that will form the basis for research throughout the lifespan of the project.

During this conference, participants were asked to consider several questions that may govern the future course of the project: What are the important scientific questions that, if answered, will have a significant, positive effect on our

${ }^{1}$ University of Arizona, Department of Geosciences, Gould-Simpson \#77, Tucson, AZ 85721.

${ }^{2}$ U.S. Geological Survey, 520 North Park Ave., Room 217E, Tucson, AZ 85719 .

${ }^{3}$ U.S. Geological Survey, 2255 North Gemini Dr., Flagstaff, AZ 860011698.

${ }^{4}$ U.S. Geological Survey, 520 North Park Ave., Room 355, Tucson, AZ 85719 . understanding of the life cycles of porphyry copper and related deposits? Which of these questions, if answered, could have a positive effect on society? Where can we best focus our efforts for maximum effect, given the 5- to 6-year lifespan of the joint project, limited funding, and the expertise of project participants? On what questions can we effectively collaborate with mining companies?

\section{Current Project Structure}

The project proposal for the first year casts a wide net, both geographically and topically. The intent was to develop a multiyear, cooperative project on the life cycles of porphyry copper and related deposits, including geology, economics, resource delineation, and consumption. On the basis of previous planning, several principal themes were considered in this first year of the project: (1) improving understanding of the geologic evolution and framework of the region and the deposits therein; (2) creating a geochemical inventory of the Earth's crust in the region and identifying those chemical elements that have unusual background values or that may constitute unrecognized potential resources; (3) understanding weathering and dispersion from deposits and mines and, in some environments, understanding reconcentration of elements, minerals, and other materials; (4) understanding the dynamics of ore-reserve growth, mine development, and production; and (5) analyzing the technological and socioeconomic factors at each historical stage of the mining life cycle and understanding the implications for mineral-resource, land-use, and environmental-management issues.

A prime strategy of this project is to look at the region as a whole, at all map and time scales, and try to fully understand the context within which these deposits and mines occur. Crustal evolution takes place on a billion-year timespan, whereas a meteorologic event significantly affecting a mine can take place in an afternoon. Although compilation of geologic, geophysical, geochemical, mining, and economic data 


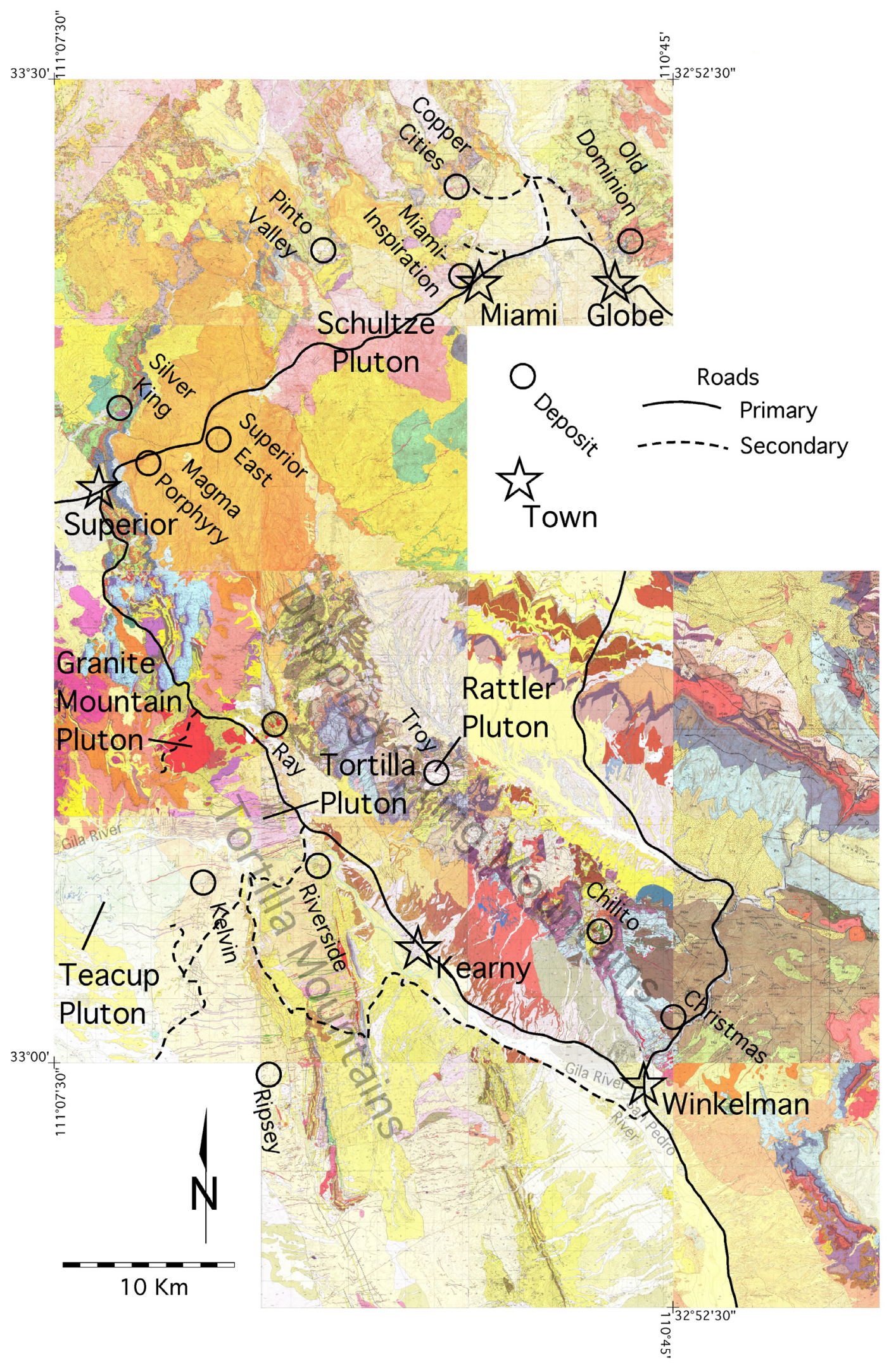

Figure 1-1. Composite geologic map of the Tortilla-Dripping Spring-Pinal Mountains area, southeastern Arizona, showing locations of towns, principal mineralized centers, and field-trip route. Compiled from U.S. Geological Survey geologic-quadrangle maps. 
are central to the project, especially in its initial years, key scientific contributions may also come from integrated, regionalscale syntheses. We expect that this project will provide many of the data needed to test a model of porphyry copper systems to be developed by the Complex Systems project led by Mark Gettings of the USGS Southwest Field Office in Tucson.

The project is currently divided into five tasks. Please note that the summaries below represent the thinking of project staff as of June 2001 and not necessarily current thinking, but are included as mileposts for the information of those not actively working on the project.

\section{Task 1: Mesozoic and Cenozoic Crustal Framework}

The foundation of most geologic investigations and of the ore-genesis part of commodity life-cycle studies is an understanding of the distribution of rocks as a function of time. Southwestern North America has a significant belt of Jurassic deformation and several associated porphyry copper deposits, world-renowned Laramide porphyry copper deposits and broadly associated deformation, and various geologic products of mid-Tertiary crustal extension with additional types of ore deposits. Products of these three episodes partly overlap in space, even within single mining districts.

Most other tasks in the project depend on the first task, an understanding of the crustal framework of the region. To be accurate, any attempt to calculate original volumes of geologic entities or geochemical masses of Laramide age must take into account Tertiary structural displacements, rotations, magmatism, alteration-mineralization, and associated erosion and deposition. Stepwise reconstructions, beginning with the latest events and working backward, are needed to yield realistic descriptions of the geology. Areas with the most complex geology require three-dimensional, as opposed to cross-sectional, restorative techniques. The ultimate objective of this task would be to construct digital, three-dimensional geologic models as a function of time, with layers for rock type, structure, and alteration-mineralization types at various time and map scales.

\section{Task 2: Regional Distribution of Chemical Elements}

The second task addresses the metallogenic aspect of the porphyry copper life cycle. To understand the processes of mineralization and elemental concentration in porphyry copper hydrothermal systems and concomitant regional environmental effects, we must ascertain accurately the background, preore, upper-crustal concentrations of important chemical elements. The porphyry copper and related deposits of the Southwestern United States and northern Mexico represent one of the densest clusters of such deposits on Earth (fig. 1-2). This clustering may be due, at least partly, to pre-Laramide contrasts in crustal composition between this metallogenic province and the rest of the North American Continent. The dense clustering and large size of hydrothermal systems associated with these deposits suggest that the regional geochemistry of the upper crust was profoundly transformed during Laramide time. However, we do not know whether the bulk composition of the upper crust was altered by the addition (and subtraction?) of certain elements, or whether the concentrations of some elements were simply rearranged. The establishment of regional geochemical inventories and chemical mass balances is critical to a rigorous analysis of ore genesis, natural dispersion of materials from these deposits through Cenozoic time, and dispersion resulting from human activity.

\section{Task 3: Characteristics and Evolution of Hydrothermal Systems}

The third task will focus in detail on individual, representative deposits and hydrothermal systems, thus complementing the regional context developed in tasks 1, 2, and 4 . The most important, widespread, and relevant products of porphyry-copper-forming hydrothermal activity are those in Mesozoic and Tertiary rocks. Although many mining districts reflect only a single episode of hydrothermal activity, some districts or mountain ranges bear the imprint of multiple episodes. Mid-Tertiary to late Tertiary time $(\sim 30-10 \mathrm{Ma})$ witnessed a widespread and important mineralizing episode that overprinted Laramide and earlier mineralization. Precise geochronologic methods can be combined with a detailed study of mineralizing magmatic and hydrothermal events to sort out, at a very fine scale, geologic events associated with ore-forming processes. Such detailed knowledge can also yield correspondingly precise information about regional tectonism and metallogeny.

\section{Task 4: Dispersion and Concentration of Materials from Porphyry Copper and Related Deposits in the Region}

The fourth task will focus on natural and anthropogenic processes of dispersion or concentration that occur in the supergene environment or at the Earth's surface in all stages of the commodity life cycle. Dispersion of materials from ore deposits commonly begins even before ore-forming processes end. Either surficial or near-surface transport processes can disperse the geochemical and mineralogic components that constitute the deposit and its alteration envelope, or such processes may serve to further concentrate and enrich components of the original deposit.

Open-pit mining methods also convert the most copper rich zones into copper and molybdenum products, waste-rock piles with sand- to boulder-size particles, and tailings piles with silt- to sand-size particles. Mine tailings are problematic because, if they are not contained, they could be a major potential source of dust, sulfide-bearing sediment, and acidic runoff; however, they are also a potential source of byproduct 


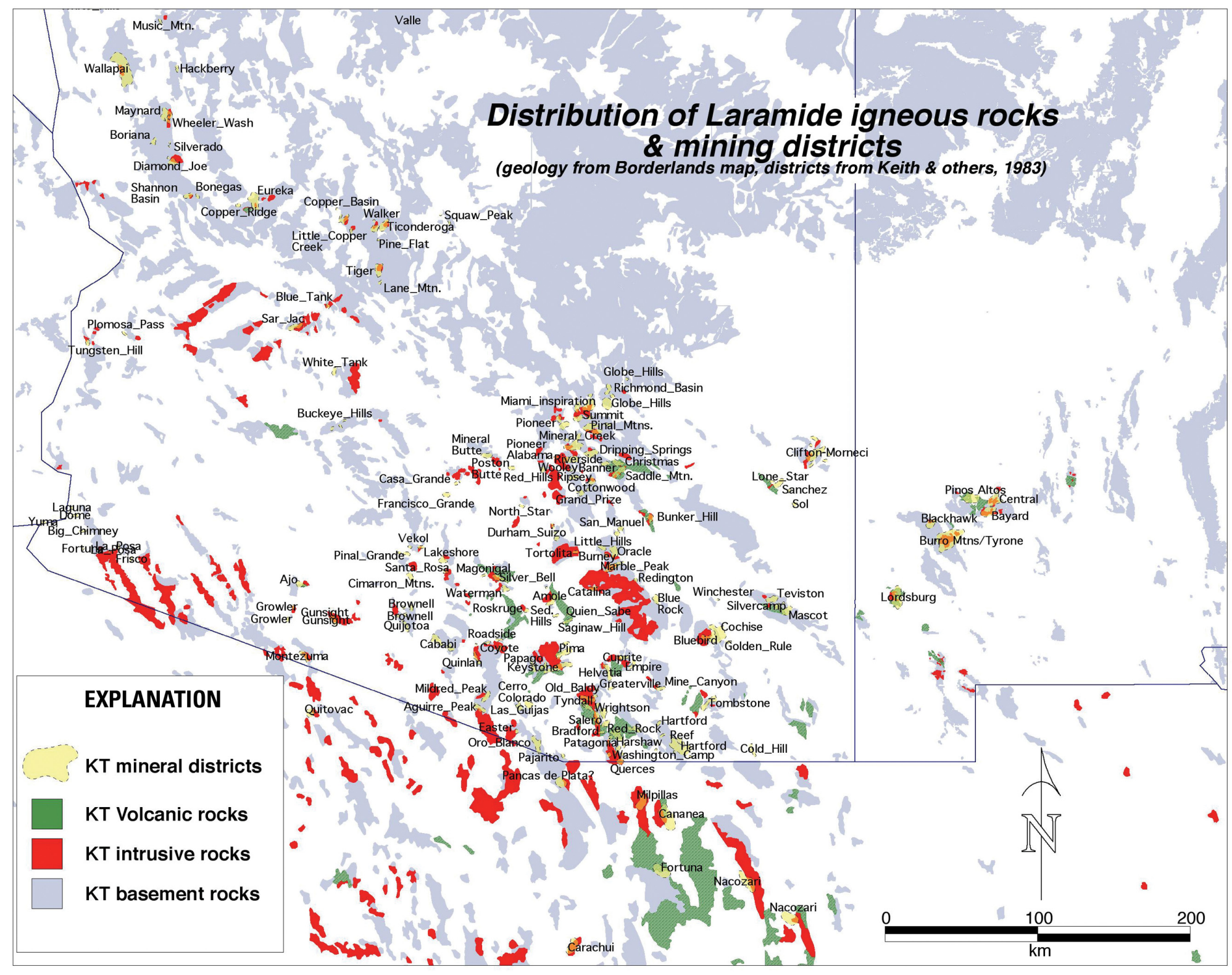

Figure 1-2. Arizona-New Mexico-Sonora, Mexico, region, showing distribution of Laramide (Cretaceous and Triassic [KT]) igneous rocks and related hydrothermal systems and older rocks in porphyry copper province. Note amount of cover and areal extent of hydrothermal systems. Generated from multiple digital sources, including the Mineral Resources Data System, mineral-district map of Arizona, and University of Arizona draft version of the Borderlands geologic map. 
elements and industrial minerals. The extraction or use of byproducts can increase revenues and reduce environmental impacts. An important question is the contribution of tailings and waste rock to various environmental impacts, relative to other known and potential sources.

Our focus is on the dispersion patterns associated with mineral deposits, but we do not limit ourselves thereto, especially for materials that may have multiple, alternative sources. Ultimately, we intend to construct models for the near-surface behavior of different groups of elements related to the deposits.

Among the weathering products of porphyry copper and related deposits, manganocrete and ferricrete may yield particularly valuable additional information, because they directly relate to the environmental fate of several elements of interest, most obviously $\mathrm{Fe}$ and $\mathrm{Mn}$ but also such trace elements as $\mathrm{Ag}$, As, $\mathrm{Cd}, \mathrm{Co}, \mathrm{Cu}, \mathrm{Ni}, \mathrm{Pb}$, and $\mathrm{Zn}$.

\section{Task 5: Historical Life-Cycle Analysis of Porphyry Copper Exploration and Mining}

The fifth task will focus on the socioeconomic and historical aspects of the copper mining life cycle in the region as a basis for predicting future issues and developments. Drawing on data and input from industry (Phelps Dodge, Asarco, Inc., and several consulting firms), State agencies (Arizona Department of Mines and Mineral Resources, Arizona Geological Survey), internal sources (Minerals Information Team, Mineral Resources Program), and original historical research, task members will assemble and analyze historical (1880-present) exploration and mining life cycles for significant porphyry copper deposits in Arizona and adjacent areas. Analysis will establish (1) a consistent and documented record of exploration, mining, production, water use, waste streams, and remediation activity at each deposit; (2) an inventory of subeconomic material (tailings, waste-rock dumps, spent heaps, low-grade stockpiles, low-grade mineralized rock); (3) a predictive understanding of the dynamics of reserve growth; (4) an investigation of the lengthening leadtime for the development of new mines; and (5) an analysis of the technologic and socioeconomic factors at each historical stage of the mining life cycle and their implications for mineral-resource, land-use, and environmental-management issues.

These studies hold the promise to advance the mineral economist's understanding of the interaction of geology, evolution of exploration concepts, incremental and groundbreaking advances in mining technology, and changing regulatory climate as determinants of mineral supply, resource-management techniques, and environmental-remediation strategies.

\section{Current Work}

Task 1.-The Tortilla Mountains, west of Hayden and Ray, Ariz. (fig. 1-1) are being remapped for rock type, structure, and alteration-mineralization. This remapping has identified new magmatic-hydrothermal centers of various ages, revealed new exposures of reverse faults involving Proterozoic crystalline rocks, refined understanding of the Tertiary sedimentation associated with the extensional unroofing process, and allowed a preliminary reconstruction of the region before the Tertiary faulting that produced more than 100-percent crustal extension. Block rotation accompanying multiple generations of Tertiary normal faults has exposed about 10 vertical $\mathrm{km}$ of the late Laramide crust. We illustrate these results with conventional map and sectional displays and a computer animation.

Task 2.-Databases are being developed for mining districts, including deposit characteristics, grade and tonnage, major and minor elements, associated igneous rocks, and alteration mineralogy, as well as to characterize the chemical composition of the Earth's crust in the region. A detailed review of National Uranium Resource Evaluation (NURE) geochemical data from the porphyry copper province is well advanced. A large batch of rock samples, representative of both fresh and altered equivalents of various parts of the crustal column, have been collected and submitted for chemical analysis. A conceptual model of geochemical mass-balance issues has been completed and applied to several chemical elements of economic and environmental interest.

Task 3.-Fieldwork in the Tortilla Mountains (fig. 1-1) includes study of the characteristics and evolution of the hydrothermal systems associated with two intrusive complexes, one associated with a large copper mine and the other with known copper prospects. At a range of paleodepth exposures, the Teacup pluton in the Grayback-Kelvin-Riverside area and the Granite Mountain pluton in the Granite Mountain-Ray area (fig. 1-1) exhibit contrasting characteristics that suggest differences in their evolution. Contrasting characteristics of deposits in the Globe-Miami-Superior area exemplify the diverse of characteristics of Laramide porphyry systems that are not well accounted for in existing deposit models. Geochronologic results from the Teacup pluton indicate that our understanding of the time-space distribution of Laramide porphyry copper deposits may be subject to considerable revision.

Task 4.-Chemical and physical dispersion processes not only may affect the environment but also may have formed or be forming exotic (displaced) metal deposits. Work has begun on natural and anthropogenic dispersion of the products of magmatic-hydrothermal systems. Samples of Tertiary sedimentary clasts and rocks, one of the products of dispersion, have been collected and submitted for chemical analysis. New remote-sensing data have been processed for several areas of the province, and computational models of hydrologic-geochemical reaction and dispersive flux have been investigated.

Task 5.-Historical-production and economic data are being compiled to understand the effects of capital investment, technological innovation, and exploration on the copper-mining industry in the region, in the hope of recognizing future trends. The complex web of material flows in the region, in single mining complexes and between various complexes and companies, influences economic decisions. 


\section{Day 1: Tucson to Globe, Ariz.}

On day 1, we make approximately 10 stops, the purpose of which is to highlight the various themes associated with the project, utilizing published work but emphasizing recent fiscal year 2002 activities by members of the project, primarily at the Center for Mineral Resources.

\section{Stop 1-1: San Manuel-Mammoth Area}

The vista at this stop offers excellent-even famousexamples of all aspects of the project and illustrates how the various tasks are interlinked. From here, we can see the Mammoth-San Manuel Mining District and oxide-leaching facilities to the north, the San Manuel sulfide concentrator, smelter, refinery, and rod plant to the south, the San Pedro riparian area in the valley below, the relatively unextended Galiuro Mountains and yet-to-be-exploited Copper Creek deposit in the mountains to the east, and one of the best-studied Cordilleran metamorphic-core complexes in the Catalina Mountains to the southwest (see figs. 1-1, 1-2). The idle processing and mining facilities are an excellent example of mass balance, cycling, and storage of components on a human time scale and a metaphor for the crustal-scale geochemical cycles that continue on a geologic time scale.

The vein deposits of the Mammoth Mining District were discovered in 1879. Significant production began in 1881 and ceased in 1959 (Bideaux, 1980; Force, 1997). Primarily a gold district, the principal Mammoth and Collins Mines also produced silver and base metals. The district also produced significant amounts of molybdenum and vanadium, primarily in the early 20th century, when advances in metallurgy and steel manufacture, as well as World War I, first created a demand for these metals (Brobst and Pratt, 1973). At 1980 prices, the total production of metals was valued at $\$ 300$ million. The district is world famous for its suite of nearly 100 $\mathrm{Cu}-\mathrm{Pb}$ minerals unmatched in richness and beauty. The total value of these minerals sold as specimens, rather than mined as ore, is estimated at \$1-5 million at 2002 prices (R.A. Bideaux, oral commun., 2002).

The presence of copper mineralization about $1.5 \mathrm{~km}$ south of the Mammoth Mining District has been known since about 1900, possibly even earlier. In 1917, geologists associated with the Magma Copper Co. drilled two holes on an outcrop of granodiorite porphyry, but the low grade $(0.8$ weight percent $\mathrm{Cu}$ ) of the rock aroused little enthusiasm at the time (Parsons, 1957). From 1917 until 1944, claims over what is now the San Manuel Mine were held by four owners of small businesses living in Superior, including an automobile dealer, an assayer, a millwright, and a saloon keeper (who had changed his name to match that of one of the most famous figures in Arizona mining, James Douglas!) (Parsons, 1957). In 1942, the owners approached the Federal Reconstruction Finance Corp. and the War Production Board and convinced them to authorize the
USGS to investigate their property. On the basis of a recommendation by the USGS, the prospect was drilled by the U.S. Bureau of Mines (Steele and Rubly, 1948). In 1944, the property was optioned by the Magma Copper Co., which obtained a \$94-million development loan from Reconstruction Finance Corp. in 1952. By 1956, the mine, a concentrator, a smelter, and a new company town were all in operation.

From 1965 to 1967, J. David Lowell made one of the most famous of all mining discoveries, using pure geological reasoning. On the basis of his early understanding of hypogene zoning in porphyry copper deposits and his knowledge that the upper boundary of the San Manuel deposit is truncated by the San Manuel Fault, Lowell deduced that the hanging-wall half of the San Manuel deposit, called the Kalamazoo, lay about $2.4 \mathrm{~km}$ to the southwest, downdip along the San Manuel Fault (Lowell, 1968). Lowell's work subsequently led to one of the best-known and influential papers in the field of economic geology (Lowell and Guilbert, 1970).

The combined San Manuel-Kalamazoo deposit is unusual because of its large tonnage (approx 1.3 billion tons), its low grade (approx 0.67 weight percent $\mathrm{Cu}$ ), and the near-absence of supergene enrichment. Byproduct elements, especially molybdenum, in addition to gold and silver, have been important to its profitability (see app. 1). The deposit was mined by a combination of block caving, open-pit excavation, and heap and inplace leaching. Not only was anode and cathode copper produced at the San Manuel complex, but also refined copper rod was manufactured.

The production part of the life cycle of the San Manuel and Mammoth Mining Districts apparently came to an end in January 2002, when BHP Copper Inc. took the San Manuel Mine (which includes the Kalamazoo deposit) off care and maintenance, on which it had been since 1998, and allowed the mine to flood (BHP Copper Inc. fact sheet, 2002). To ever restart production will be difficult and expensive. Although the smelter is still on care and maintenance, the epilog to this story will probably be an indefinite period of reclamation and environmental monitoring. More than 500 million tons of potential ore remain in the ground (see app. 1 ), making it clear that the mine was closed because of economic conditions, not exhaustion of resources.

The San Manuel and Mammoth Mining Districts show that many factors can play a role in the life cycle of a deposit or mining district, in addition to the familiar factors of grade, tonnage, mining costs, and metal prices. Other important factors include - in the case of the San Manuel and Mammoth Mining Districts - advances in mining and metallurgy, new uses for formerly worthless metals, such unusual byproducts as mineral specimens and smelter-generated sulfuric acid for heap leaching, advances in scientific understanding and the construction of ore-deposit models, government assistance, and-possibly most importantly here-wars, both hot and cold.

The Mammoth and San Manuel Mining Districts together form an exemplar and impetus for the various avenues of research being pursued or contemplated in this project. The 
Au-Ag-Mo-V-Pb-Zn veins of the Mammoth Mining District formed during mid-Tertiary extensional faulting that affected virtually the entire Sonoran copper province. Fundamental uncertainty still exists concerning the extremely important mechanism of tectonic denudation associated with metamorphic-core complexes and crustal extension (Dickinson, 1991). The San Manuel-Kalamazoo deposit was created by devolatilization of intermediate-composition igneous bodies that intruded during compressional Laramide orogenic events (tasks 1,3). At least some important components of the mid-Tertiary Mammoth ore deposits may have originated from the older San Manuel-Kalamazoo deposit through dispersion and reconcentration of various chemical elements (Kamilli, 1997). If so, this origin would explain the mystery, discussed by Peterson (1938) and Creasey (1950), of the source of molybdenum and vanadium for the Mammoth deposits. This speculation needs further investigation. Although Laramide and Tertiary structures have been studied particularly intensively here (Creasey, 1965; Dickinson, 1991; Force and Dickinson, 1993; Force, 1997), an even more "accurate picture of ore geometry and tectonic history may lead to further discoveries in this district" (Force and Dickinson, 1993, p. 7). The flooding of the San Manuel-Kalamazoo Mine and the presence of tailings near the San Pedro River will almost certainly increase the rates of dispersion of constituents that were originally more concentrated and consolidated before mining began (task 4). Finally, the extensive and unusual history of the two mining districts, and the nearly complete life cycle of a self-contained mining, processing, and refining industrial complex (complete with company town), make these two mining districts prime targets for further study.

\section{Tortilla Mountains Area}

Study of the mid-Tertiary sedimentary rocks of the region is essential to understand the regional faulting and tilting history, as well as erosional and depositional processes and crustal-scale recycling of materials. For example, where Tertiary sedimentary deposits have been tilted, bedrock has been tilted by at least the same amount (depending on how much tilting occurred before deposition preserved the record).

Looking at the environment of deposition and the type of material moved, we can better understand the dispersion of metals from mineralized systems in the surface environment at different stages of geologic history. If highly altered and mineralized material is exposed to surface conditions and weathered, we can look for evidence of how it was dispersed into the surface environment. Was it more concentrated by mass movement or short transport distances, or was it diluted by significant mixing with other material, sluggish erosion rates, or rapid dispersion over a larger area? Through provenance studies of sedimentary rocks and geochemical analyses within the context of that understanding, we can assess the geochemical flux in the environment at the time of erosion and deposition of those rocks (figs. 1-3 to 1-5).

\section{Hackberry Wash}

In Hackberry Wash, southwest of Kearny, Ariz. (fig. 1-1), we measured and described approximately 1,900 $\mathrm{m}$ of dominantly fluvial sedimentary rocks with locally interbedded alluvial deposits. This part of the stratigraphic sequence of Tertiary clastic sedimentary rocks (locally and regionally constrained by ages on interbedded volcanic rocks) has been correlated with the Cloudburst Formation, in the vicinity of San Manuel to the south, by Dickinson (1991), who named these rocks the "Hackberry Member" of that formation. The area was mapped in detail by Cornwall and Krieger (1975a) and Krieger (1977).

At the bottom of the measured section, the sedimentary rocks rest on upper Precambrian Troy quartzite with a slight angular unconformity. The dips of the sedimentary deposits at the unconformity are near-vertical and progressively (though not uniformly) decrease upsection, finally recording approximately $90^{\circ}$ of Oligocene through Miocene tilting (fig. 1-6). In a broad sense, the dips fan upward (growth beds); however, in detail, episodic tilting appears to be separated by periods of deposition during tectonic quiescence. Bedding dips progressively decrease from near-vertical at the unconformity to approximately $50^{\circ}$, suggesting $35^{\circ}-40^{\circ}$ of rotation during deposition of these rocks. Dips are consistent with little variation for several hundred meters upsection until another $20^{\circ}$ of tilting yields dips from about $30^{\circ}$ to about $50^{\circ}$. The last $30^{\circ}$ (or more?) of tilt is recorded in sedimentary deposits above the measured section in Hackberry Wash. This episodic fanning of dips suggests three periods of tilting (on possibly three sets of faults).

Regionally, the various source rocks for the Tertiary sedimentary deposits vary significantly and include clasts of all older rocks. Locally, however, the clast content of the sedimentary deposits commonly is nearly constant. In the Hackberry Wash section, we conducted pebble counts approximately every $50 \mathrm{~m}$ and noted a variation in the overall column, but the clast content was commonly consistent over significant intervals, punctuated by relatively abrupt changes (fig. 1-6). Near the base of the section, the deposits are generally coarse, poorly sorted, and angular, suggesting short transport distances in a relatively high energy environment. The clasts are dominated by siliciclastic sedimentary rocks of the Apache Group, Paleozoic carbonates, and some porphyritic igneous intrusive rocks. From about 100 to $400 \mathrm{~m}$ above the base of the section, several landslide megabreccias (Krieger, 1977) are interbedded with the sedimentary rocks described above. These moderately to locally very thick (>100 m) oligomictic sedimentary deposits are typically brecciated but internally still exhibit extensive original stratigraphic and sedimentary structural features, suggesting large-scale mass movement. The landslide blocks, which occur in layers dipping from $50^{\circ}$ to about $60^{\circ}$ (that is, $\sim 30-40^{\circ}$ of original tilt), may be situated where bedrock sedimentary deposits were tilted to an angle at which stratigraphic horizons became unstable slip planes.

Within the landslide megabreccias are several beds of Mesozoic intermediate-composition volcanic rocks of the Wil- 
liamson Canyon Volcanics. Intermediate-composition volcanic rocks are the dominant clast type in the sedimentary section above the megabreccias in the Hackberry Wash section, with fewer clasts of siliciclastic rocks and carbonates that probably are also Williamson Canyon Volcanics, although they may be mid-Tertiary equivalents to those in the Galiuro Mountains to the southeast. The sedimentary deposits also become progressively finer grained and relatively better sorted upsection, though still immature, and exhibit sedimentary structures consistent with a more saturated environment, such as sand dikes, lode casts, and growth folds, as well as common mudcracks and mudcurls that suggest repeated subaqueous and subaerial exposure (fig. 1-6). The paleoenvironment of deposition was probably similar to the contemporary environment. (Compare the sedimentary material being deposited in the modern wash with the Tertiary sedimentary deposits observed in outcrops along the wash.)
The clast content of sedimentary rocks varies, however, throughout the Hackberry area and vicinity (fig. 1-7). North of the Hackberry Wash section, clasts are dominantly of coarsegrained porphyritic granite (Precambrian Oracle Granite) and porphyritic and fine- to medium-grained equigranular, felsic to intermediate-composition igneous rocks (probably various Laramide intrusive rocks).

Relatively few altered clasts occur in the Hackberry Wash section. Near the base of the section (within and below the landslide megabreccias), carbonate clasts show partial to complete replacement by silica+pyrite (oxidized to goethite) or pyrolusite (similar to the distal carbonate replacement near the Magma Porphyry deposit at Superior). In the Hackberry Wash section, generally 1 to 10 percent (locally more) of igneous clasts are (minor) chlorite \pm epidote \pm rare pyrite (oxidized). To the north, altered clasts are more common and locally are strongly quartz-sericite-pyrite bearing (oxidized). Compare

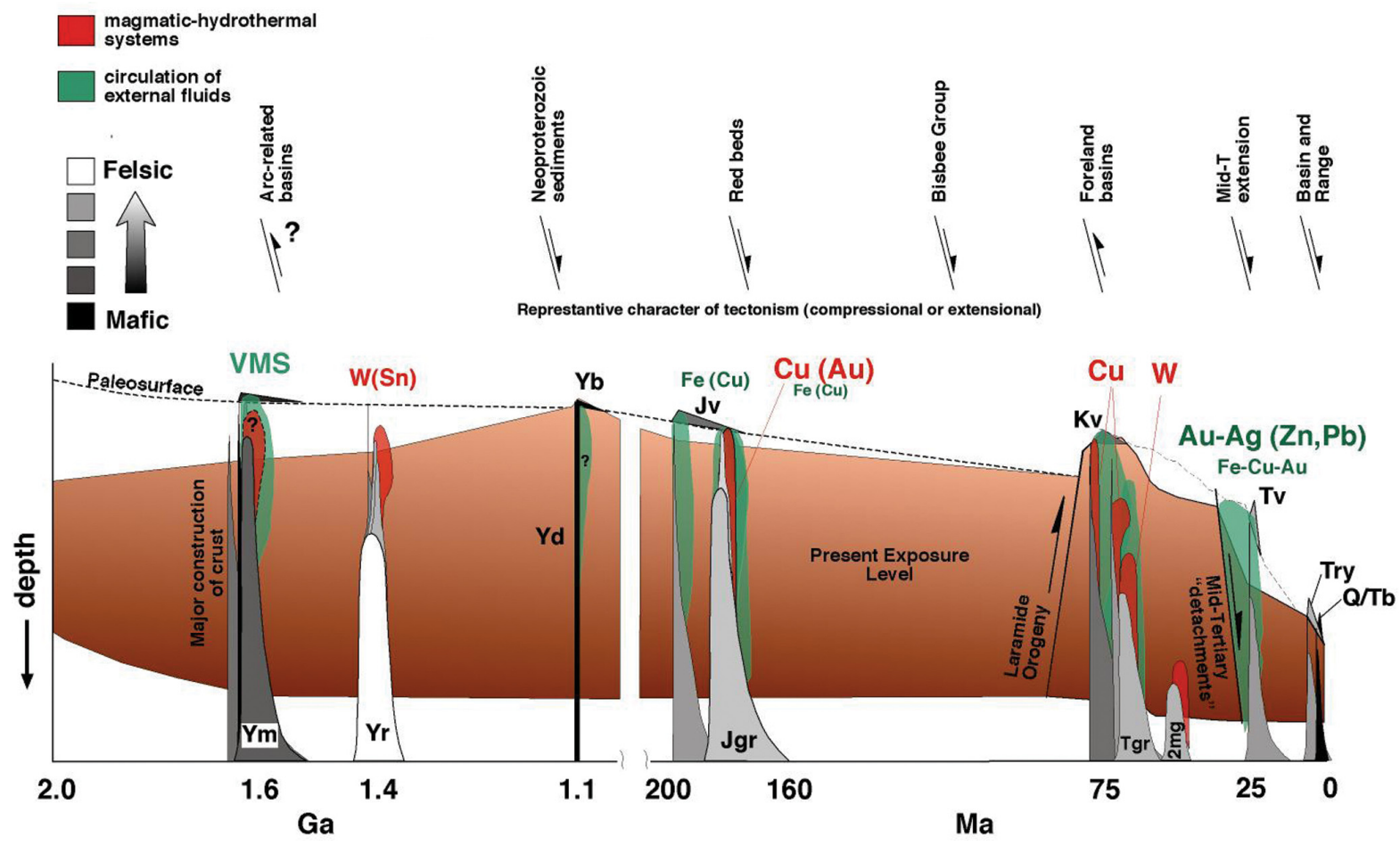

Figure 1-3 Time-space diagram illustrating evolution of magmatic-hydrothermal systems. Units: 2mg, Laramide twomica granites; Jgr, intermediate-composition to felsic Jurassic granitoids; Jv, intermediate-composition to felsic Jurassic volcanic rocks; Kv, Late Cretaceous volcanic and volcaniclastic rocks; 0/Tb, Late Cenozoic basaltic dikes and flows; Tgr, Laramide (Late Cretaceous to Paleocene) intermediate-composition to felsic granitoids; Try, Late Cenozoic rhyolitic volcanic rocks; Tv, mid-Tertiary intermediate-composition to felsic volcanic rocks; Yb, Proterozoic Y basalt flows; Yd, Proterozoic $Y$ diabase sills and dikes; $Y$ m, Proterozoic $Y$ Madera diorite and related intermediate composition arc granitoids; Yr, Proterozoic Y Ruin granite and equivalents. Mineralizing systems: $A u-A g(Z n, P b)$, epithermal vein and replacement precious- and base-metal deposits; Cu, copper(-molybdenum-gold-silver) porphyry deposits; Cu(Au), copper(-gold) porphyry deposits; $\mathrm{Fe}(\mathrm{Cu})$, Fe oxide(-copper-gold) occurrences; Fe-Cu-Au, detachment-type hematite-copper-gold deposits; VMS, volcanogenic massive sulfide systems (central Arizona), W, tungsten(-molybdenum-copper) greisen and skarn deposits; W(Sn), tungsten(-tin) greisen and pegmatite deposits. Down arrows indicate sedimentation associated with extension; up arrows indicate sedimentation associated with compression. 
these altered clasts with the clasts viewed later at Copper Butte (stop 1-9) (fig. 1-7).

\section{Stop 1-2: Middle of the Hackberry Wash Section}

(UTM 506,905 E./3,655,425 N.) Erosion in the modern drainage of Hackberry Wash has beautifully exposed tilted strata of the mid-Tertiary sedimentary section. Here we see excellent exposures of moderately dipping, dominantly fluvial sedimentary deposits approximately $1,200 \mathrm{~m}$ above the Tertiary unconformity. The sedimentary rocks are finer grained and, though poorly sorted, relatively better sorted than rocks lower in the section and exhibit structures characteristic of a water-saturated environment, such as sand dikes and growth folds and such features as mudcracks and mudcurls that indicate periodic subaerial exposure. Look at some of the clasts in these sedimentary rocks: they are dominated by intermediate-composition volcanic rocks, presumably Late Cretaceous rocks of the Williamson Canyon Volcanics. Several percent of the clasts are chloritized and (or) epidotized and locally weakly pyrite bearing (oxidized to goethite).

\section{Stop 1-3: Base of the Hackberry Wash Section in Falls Canyon}

(UTM 505,540 E./3,653,080 N.) We have now traveled downsection (to the west) in the tilted mid-Tertiary strata. Notice how the dips of bedding have increased to near-vertical. At the head of Falls Canyon (informal local name), we see exposures of Precambrian Troy Quartzite slightly overturned to the west (upsection to east). The base of the Tertiary section is not exposed here, but a few meters above the quartzite
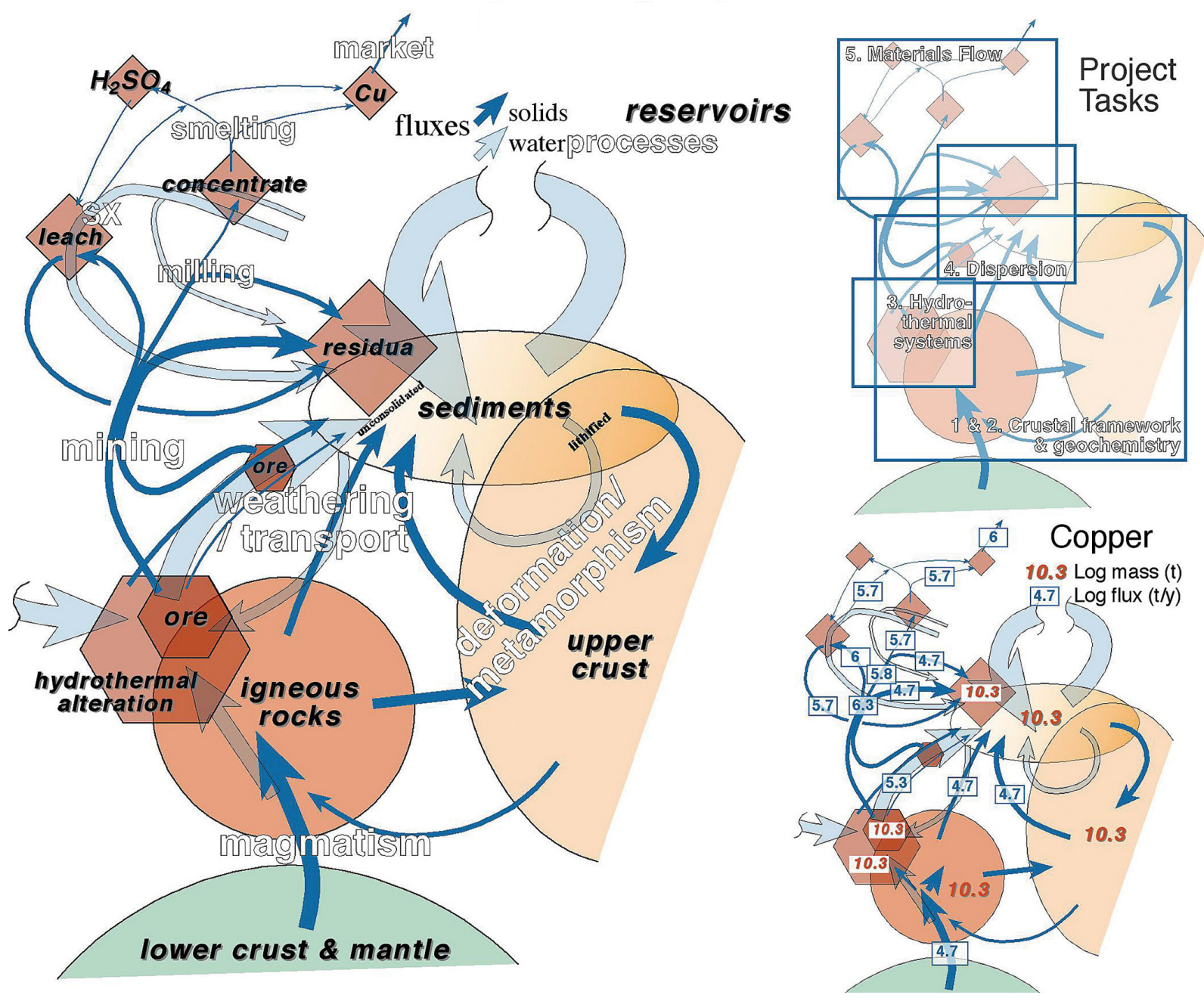

Figure 1-4. Schematic diagrams showing generalized mass flow in the crust, at the surface, and during mining in relation to project tasks. Note different time scales. Copper and sulfur are schematically illustrated by using plausible but as yet poorly documented values. Inferring, documenting, and applying these relations and those for water and many other elements is central to the overall project. Analogous "geochemical cycle" templates might be applied in many other situations requiring an understanding of the life cycles of materials. 


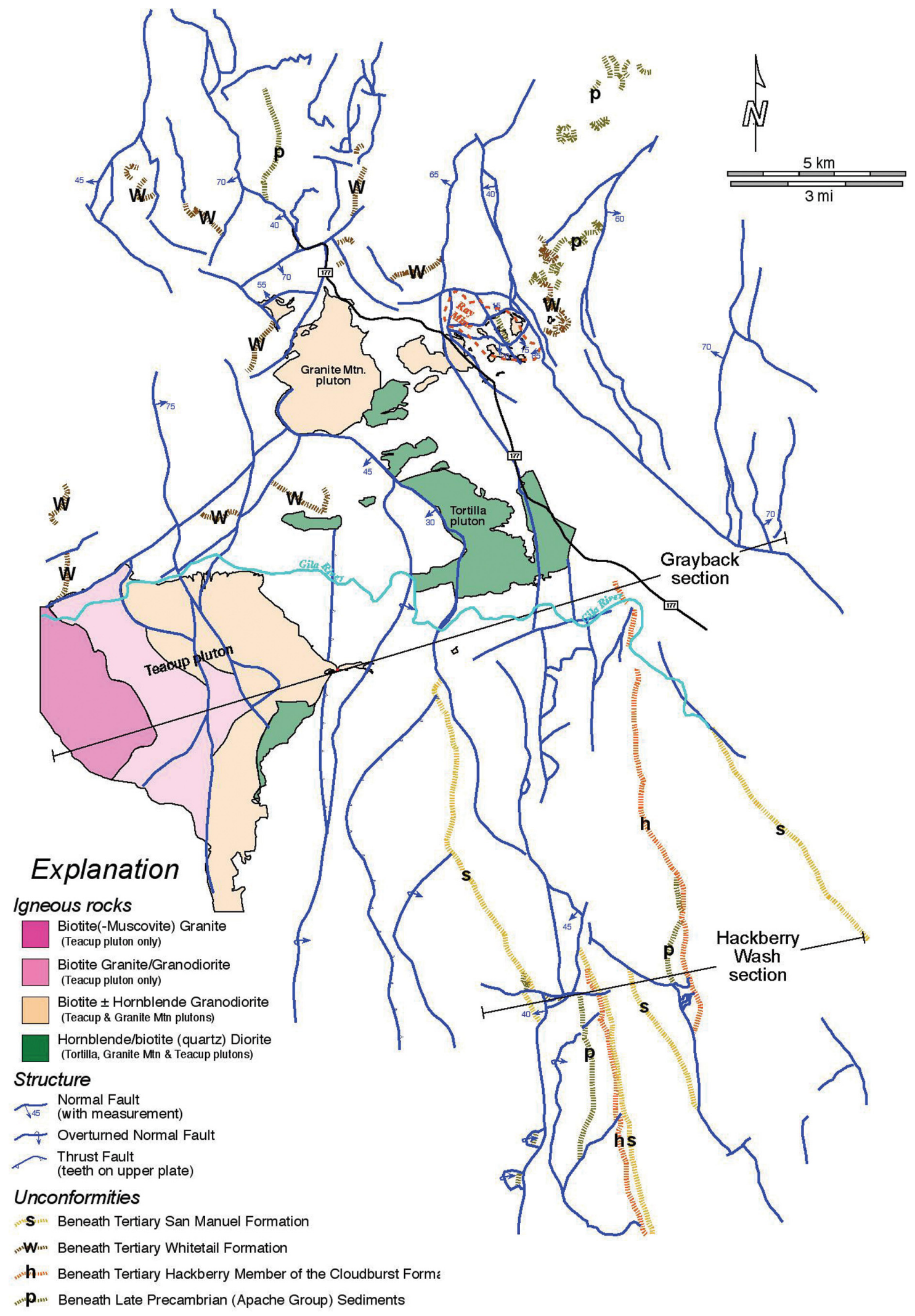

Figure 1-5. Schematic map of the northern Tortilla Mountains, south-central Arizona (figs. 1-1, 1-2), showing locations of principal faults, unconformities, and some major intrusive centers. Based on published geologic-quadrangle maps, with new observations and interpretations by 2002 University of Arizona class under the Educational Component of the National Cooperative Geologic Mapping Program (EDMAP). 
Symbols

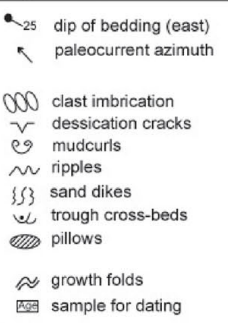

1) Paleocurrent azimuth

$\uparrow_{65}$ Bedding dip
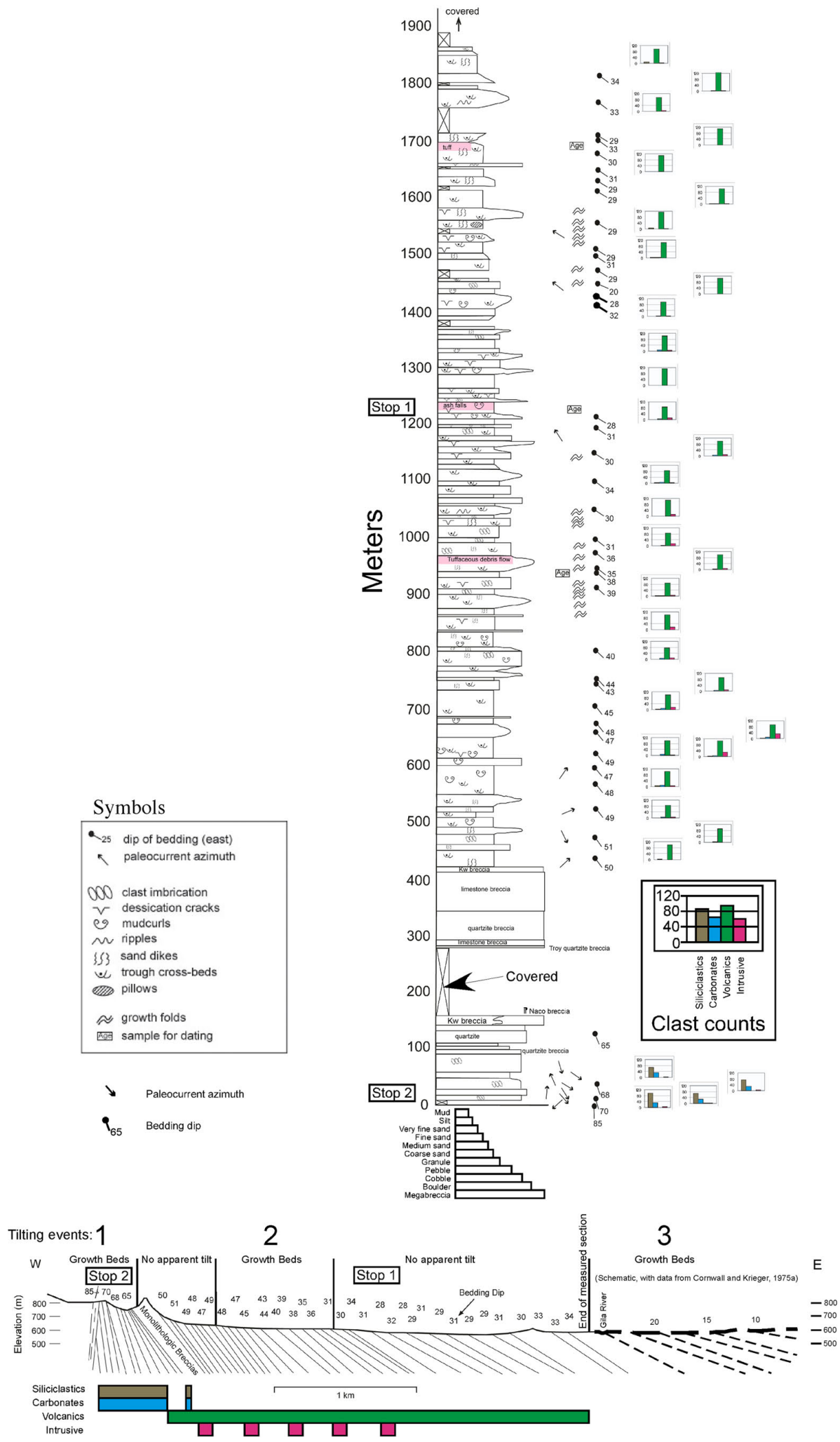

Figure 1-6. Stratigraphic column and schematic cross section along measured section in Hackberry Wash (fig. 1-5), northern Tortilla Mountains, south-central Arizona (figs. 1-1, $1-2)$, showing area of stops $1-2 a$ and $1-2 b$. From new observations and interpretations by 2002 University of Arizona class under the Educational Component of the National Cooperative Geologic Mapping Program (EDMAP). 


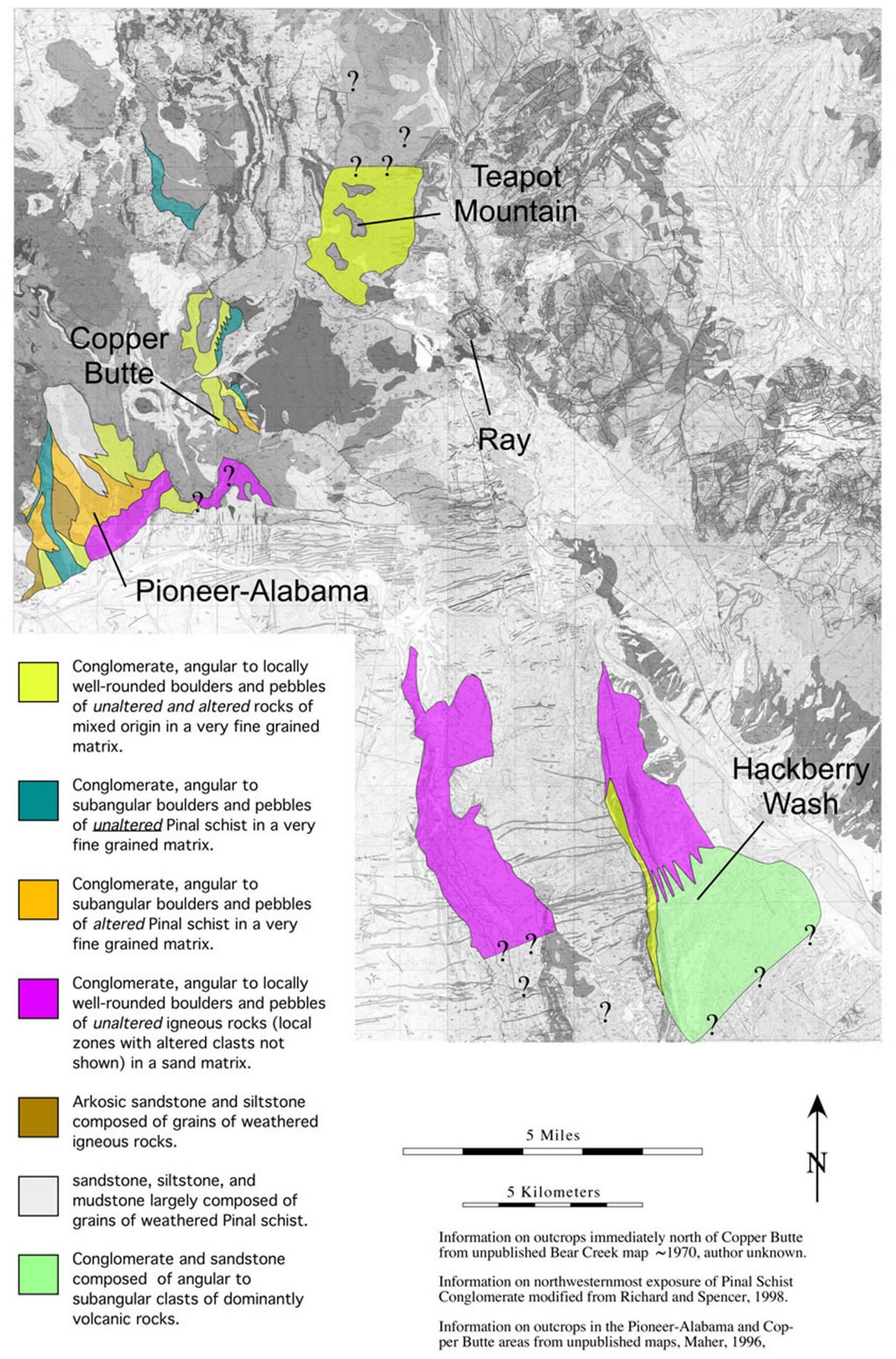

Figure 1-7. Geologic map of the northern Tortilla Mountains and adjacent valleys, southcentral Arizona (figs. 1-1, 1-2), showing distribution of clast types in mid-Tertiary sedimentary rocks. Compiled by David Maher on the basis of observations by many individuals in 2002 University of Arizona class under the Educational Component of the National Cooperative Geologic Mapping Program (EDMAP). Information on outcrops immediately north of Copper Butte from anonymous (unpub. data, ca. 1970); information on northwesternmost exposure of Pinal Schist Conglomerate modified from Richard and Spencer (1998); information on outcrops in the Pioneer-Alabama and Copper Butte areas from David Maher (unpub. data, 1996). 
immediately to the north, the Tertiary strata dip $85^{\circ}$ E. Only a few degrees of angular discordance exists here between the Precambrian and mid-Tertiary rocks. Restoration of the midTertiary rocks to pretilting horizontal requires the underlying rocks to be restored to near-horizontal.

The sedimentary deposits are much coarser grained and less well sorted here than at stop 1-2 and contain some clast-supported breccia, indicating more debris-flow (alluvial) deposits. Also, large oligomictic breccia bodies locally exhibit internal stratigraphy, probably representing large landslides that came from uplifted highlands nearby during the early stages of faulting and tilting.

The clasts in these outcrops are dominantly siliciclastic and carbonate rocks, with minor shallow igneous intrusive and volcanic rocks. A few igneous clasts are mildly chloritized and (or) epidotized, and some carbonate clasts exhibit partial or complete replacement by quartz+pyrite (oxidized to goethite) or pyrolusite. These rocks may have been weathered from the distal environment of a porphyry-related hydrothermal system. Driving eastward up Queen Creek from the town of Superior, look for small trenches and adits in the hillsides. These excavations are prospects on quartz+sulfide (oxidized) and Mn oxide deposits related to the Magma Porphyry hydrothermal system.

\section{Stop 1-4: Upper Ripsey Wash}

(UTM 502,700 E./3,653,750 N.) The dirt road along this ridge provides a vantagepoint for the eastern Tortilla Mountains. The area in view is the subject of excellent USGS maps (Krieger, 1974, Cornwall and Krieger, 1975a, b). Recent work (Schmidt, 1971; Dickinson, 1991, 1996, 1998, 2001; Howard, 1991; Howard and Foster, 1996; Richard and Spencer, 1998) is building on earlier work but is resulting in a substantially different view of the local geology.

Tertiary extension in the area began about $25 \mathrm{Ma}$. Preliminary results suggest that the crustal extension near this site can be regarded as related to at least three sets of superimposed sets of normal faults, all west dipping, that initiated at about $60^{\circ}$ and rotated to lower angles during faulting. Later sets of faults crosscut and dismembered earlier sets. The earliest set is rotated through horizontal and now dips gently to moderately east (although the slip direction was westward), the second set now dips gently west, and the youngest set dips moderately west. Sequential reconstruction (fig. 1-8) indicates that the crust in the area has been extended at least 100 percent, and we believe that the crustal extension was superimposed on Laramide reverse faults which are more extensive than previously mapped.

\section{Grayback-Riverside Area}

The Grayback-Riverside area (fig. 1-9) contains a structurally dismembered composite Laramide intrusive center (Teacup pluton and shallower equivalents), including multiple associated hydrothermal features associated with mineralization in the Kelvin and Riverside Mining Districts (fig. 1-1). Three stops in this area are intended to stimulate discussions about Laramide magmatism, the types and scales of hydrothermal systems, and framework geology from Proterozoic granitoids through mid-Tertiary dismemberment to modern natural dispersion of materials. Subsequent stops at the Ray Mine overlook and at Copper Butte examine the next igneous center to the north and its subsequent dispersion.

\section{Stop 1-5: Radio Tower-Overlook of the Teacup Intrusive Center and Associated Hydrothermal Systems}

(UTM 494,996 E./3,658,806 N.) The highpoint here gives a splendid view of the northern Tortilla Mountains, including at least four dismembered magmatic-hydrothermal systems. The stop is located at the end of a good dirt road that branches off the Florence-Kelvin Highway at the crest of the range (fig. 1-9). This stop allows an opportunity to (1) point out regional geography, (2) summarize characteristics of the nearby magmatic and hydrothermal systems, and (3) consider broader issues of the concentration and dispersion of mineral deposits. Information given at this stop is based on recent mapping and new interpretations grounded in extensive earlier geologic mapping (Schmidt, 1971; Cornwall and Krieger, 1975a, 1975b).

Farther south in the Tortilla Mountains, Laramide plutons and dike swarms intrude various Proterozoic rocks. Paleozoic and Cretaceous supracrustal rocks are exposed in the Dripping Springs Mountains to the east and north (fig. 1-1) but are erosionally stripped (or structurally hidden) in this part of the Tortilla Mountains. Dismemberment and rotation along multiple sets of mid-Tertiary normal faults has laid large parts of these systems out on their sides.

Within view are areas containing varyingly convincing evidence for hydrothermal (metasomatic) systems ranging in age from the 1.66-Ga Madera Diorite to those associated with Miocene extension and volcanism. The most compelling evidence is:

- Tourmaline-rich greisenization within the $1.45-$ Ga Ruin Granite

- Multiple episodes comprising at least two large composite Laramide porphyry copper(-molybdenum) systems (the Ray-Granite Mountain system to the north and the Riverside-Kelvin system along this trend)

- Greisenization and $\mathrm{Mo}(-\mathrm{Cu})$ mineralization, with Laramide two-mica granites.

The distribution of Laramide intrusive centers and their associated hydrothermal alteration is mapped in figure 1-9.

The radio tower stands on a ridge consisting of a conspicuous Laramide porphyry dike associated with the tilted Teacup pluton ( $73 \mathrm{Ma}$, based on new U-Pb ages by the University of Arizona). The Teacup intrusion is zoned from (oldest, 73.8 


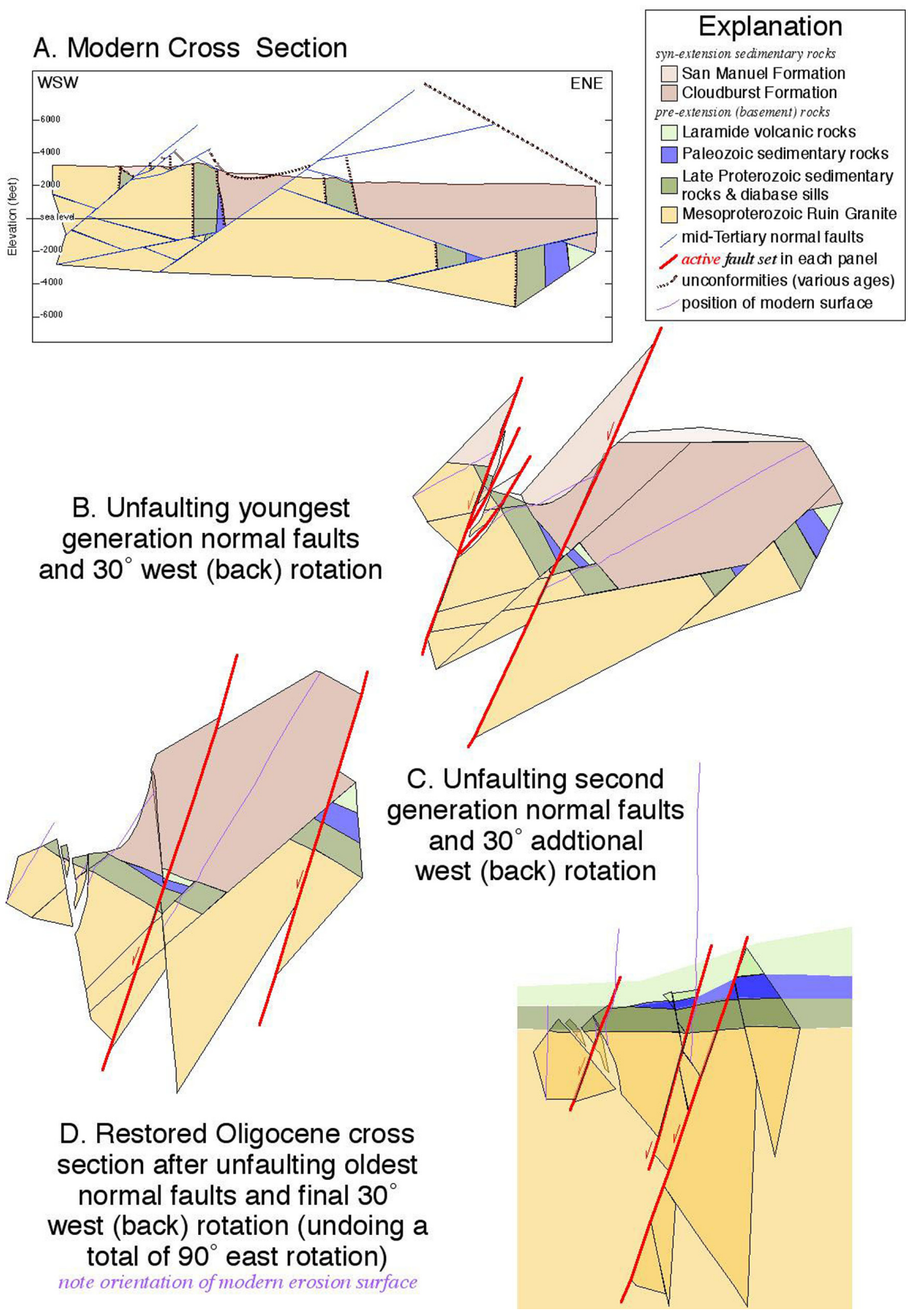

Figure 1-8. Sequential palinspastic reconstruction of mid-Tertiary faulting in the Hackberry/Ripsey Wash area (fig. 1-5), Tortilla Mountains, south-central Arizona (figs. 1-1, $1-2)$. A, Modern cross section. B, Unfaulting youngest-generation normal faults and $30^{\circ}$ of westward (back) rotation. C, Unfaulting second-generation normal faults and $30^{\circ}$ of additional westward (back) rotation. D, Restored Oligocene cross section after unfaulting oldest normal faults and final $30^{\circ}$ of westward (back) rotation, undoing a total of $90^{\circ}$ of eastward rotation. Note orientation of modern erosional surface. Compiled by Eric Seedorff. 


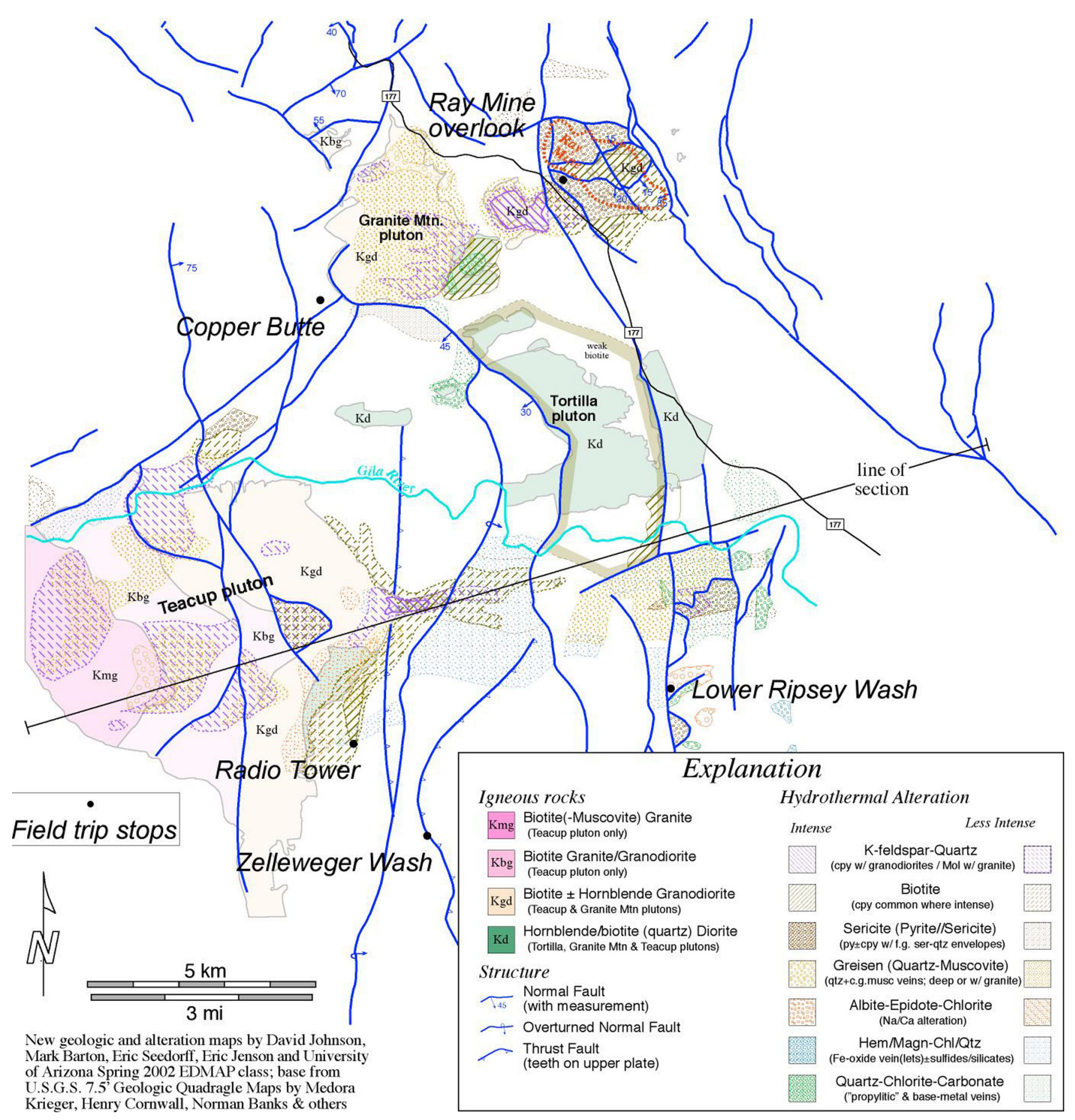

Figure 1-9. Schematic map of the northern Tortilla Mountains, south-central Arizona (figs. 1-1, 1-2), showing generalized distribution of hydrothermal alteration, igneous rocks, principal faults, and field-trip stops. Area has largely been laid out on its side by midTertiary normal faulting. Note extent of hydrothermally altered rocks (see cross sections and reconstruction, fig. 1-10). Base from U.S. Geological Survey geologic-quadrangle maps of the Sonora, Teapot Mountain, Kearny, and Grayback quadrangles, with new alteration and structural mapping by David Johnson, Mark Barton, Eric Seedorff, Eric Jensen, and 2002 University of Arizona class under the Educational Component of the National Cooperative Geologic Mapping Program (EDMAP). 
Ma) hornblende-biotite monzodiorite and granodiorite on the east (paleotop; paleodepth, 4-6? km), through biotite granodiorite, to (youngest, $72.7 \mathrm{Ma}$ ) biotite \pm muscovite granite on the west (near Grayback Mountain; paleodepth, $8-10 \mathrm{~km}$, based on structural reconstruction). Conspicuous quartz-K-feldspar veins, aplites, and quartz-muscovite ( \pm molybdenite \pm chalcopyrite) veins are associated with the two-mica granite. Northeast of the radio tower, a conspicuous dike set extends eastward from the apex (cupola) of the Teacup pluton toward the Kelvin copper prospect, an area of intense K-silicate and subordinate hydrolytic alteration (Wilkins and Heidrick, 1995). Locally intense albite-chlorite-epidote-bearing alteration lies outward of the system's core and zones upward into structurally shallower magnetite, hematite, chlorite, and $\mathrm{Cu}$ sulfide mineralization. Farther east, across Ripsey Wash and eastward to the Gila River near the town of Riverside, quartz-sericitepyrite-bearing alteration represents the upward continuation of this system.

Pieces of the Ray-Granite Mountain hydrothermal system and its dispersion trail in the Miocene Whitetail Formation (fig. 1-9; see fig. 1-6) are visible in the hills to the north and east across the Gila River. Conspicuously layered Miocene volcanic rocks can be seen to varyingly overlie Whitetail and older rocks. Stops 1-7 and 1-8 (see below) contain more detail about that area, which includes the Ray and Copper Butte deposits. The Copper Butte deposit occurs at the prominent pyramidal, drill-road-laced hill in the middle distance.

The purpose of this stop is to highlight current understanding and the need for future work on the distribution and evolution of hydrothermal systems (fig. 1-10). Our current understanding of these systems leaves much to be desired, in spite of considerable work by USGS, industry, and academic geologists.

\section{Stop 1-6 (Optional): Zelleweger Wash-a Laramide Thrust Fault(?) in Ruin Granite}

(UTM 496,189 E./3,657,154 N.) This stop is in Zelleweger Wash along the Florence-Kelvin Highway between the turnoff to the radio tower and the bottom of Ripsey Wash (fig. 1-1). A well-indurated east-dipping cataclasite zone here may represent the trace of a Laramide thrust fault (see fig. 1-9).

As discussed at earlier stops, regional geologic evidence points to eastward-directed thrust fault(s) along the general trend of San Pedro-Gila Valley that extends northward to Superior. Structural repetition is readily identifiable in the supracrustal rocks but considerably more difficult to recognize in older Proterozoic rocks, where markers are less obvious. Nonetheless, if such thrust faults are present to the east, they must project into the deeper rocks in this area. This area was hypothesized as a reasonable location for a thrust fault, on the basis of discontinuities (structural truncations?) in Proterozoic diabase sheets and the absence of discontinuities in crosscutting Laramide porphyry dikes.

\section{Stop 1-7: Lower Ripsey Wash-Modern Natural Dispersion from Upper Parts of the Kelvin- Riverside Hydrothermal Center}

(UTM 501,530 E./3,659,340 N.) This stop is $100 \mathrm{~m}$ east of the poor dirt road that heads southward along the route of the Arizona Trail. Our purpose here is to consider the natural dispersion of sulfate, metals, and other components by chemical and mechanical means. What are the natural contributions to modern surface- and ground-water fluxes, and what is the time-integrated (geologic) record of this dispersion? Is this record significant in comparison with other sources, and, if so, for what components?

At this stop, modern acid ( $\mathrm{pH} \sim 4$ ) seeps emanate from sericitized, pyrite-bearing Ruin Granite adjacent to a large but relatively unaltered early Laramide breccia pipe. The waters have deposited small amounts of ferricrete and manganocrete in a young channel incised into older gravel.

Evidence for natural oxidation of sulfide-rich rocks and dispersion ( \pm local enrichment) of sulfur, copper, iron, manganese, and other materials is abundant throughout the Tortilla Mountains east of Ripsey Wash for at least $5 \mathrm{~km}$ south of the Gila River (fig. 1-1). For example, similar sulfate seeps and Fe-Mn-cemented sedimentary rocks occur along this trend to the south and east, where they are exposed in drainages that cut across fault slices of sericitized rock. To the northeast, toward the inferred core of the Kelvin-Riverside hydrothermal system, intensely leached quartz-sericite-pyrite-bearing material overlies rocks with secondary enrichment of copper (now $\mathrm{Cu}$ oxides).

The purpose of this stop is to consider the dismemberment and dispersion of the Laramide magmatic-hydrothermal system(s). A preliminary cross-sectional palinspastic restoration of the distribution of rock types and alteration minerals shows how the systems may have looked before the inception of Tertiary crustal extension (fig. 1-11). The cross section extends from the west edge of the Grayback quadrangle to the east edge of the Dripping Springs Mountains, passing through Grayback Peak, the Kelvin cupola on the composite Teacup pluton, and the Riverside area (fig. 1-1). The Grayback section is twice as long as - and more complex than-the section in the Hackberry Wash area at stops 1-2 and 1-3. The Grayback section is interpreted to contain the same fault sets as those observed in Hackberry Wash (three generations of normal faults that initiated as moderate to steeply west dipping normal faults). In addition, it includes a fourth set of west-dipping normal faults that are all moderately displaced, an oblique, southwesterly dipping fault at the base of the Dripping Spring Mountains (Diabase Fault), and a late set of east-dipping normal faults. Moreover, the normal faults appear to cut several Laramide(?) reverse faults, which truncate sheets of Proterozoic diabase but are, in turn, cut by the Teacup pluton and its associated dikes.

The restoration (fig. 1-11) was generated by progressive unfaulting and unrotating of the system, from latest to earli- 

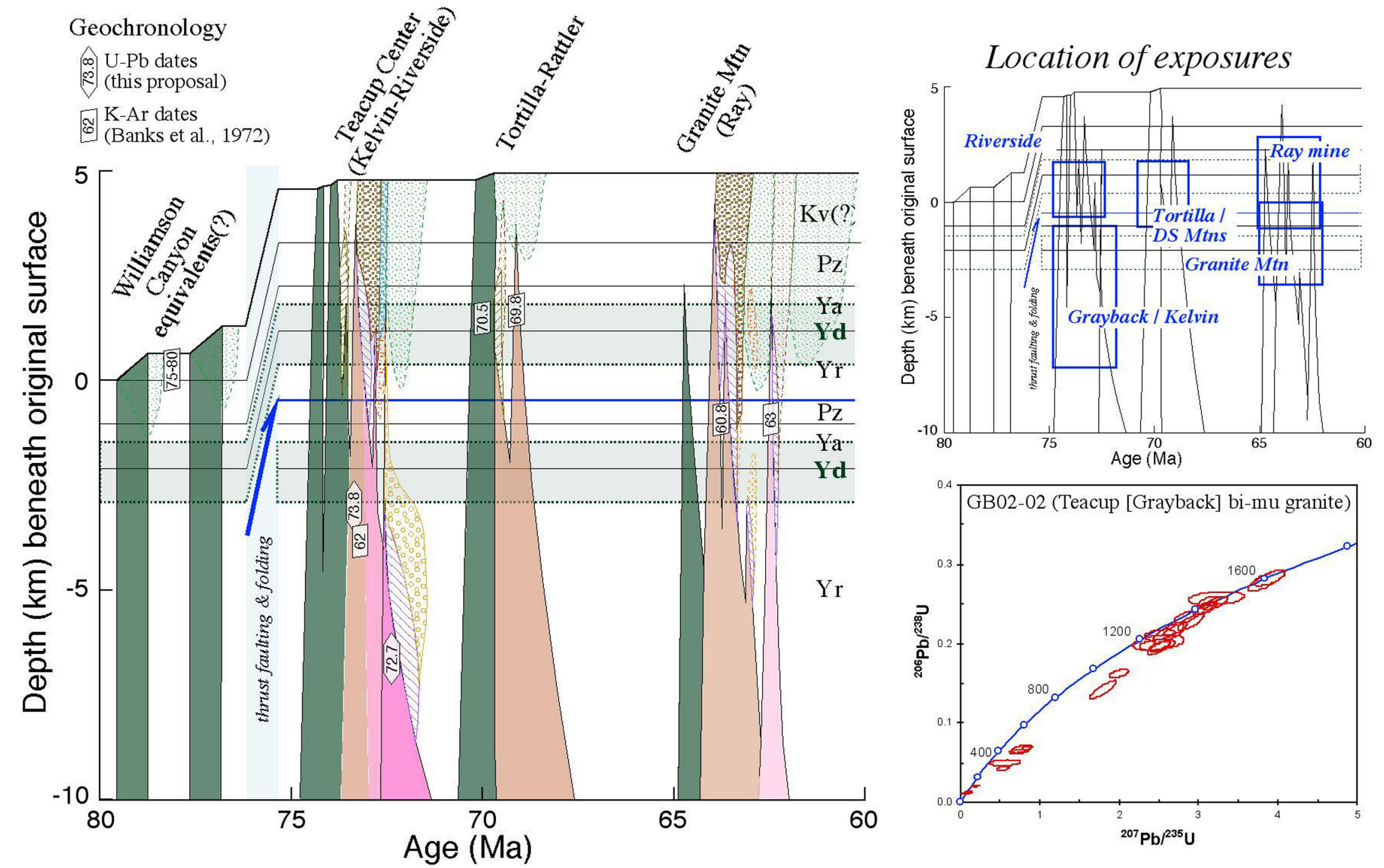

Figure 1-10. Evolution of principal Laramide magmatic, hydrothermal, and structural features in the northern Tortilla Mountains, south-central Arizona (figs. 1-1, 1-2). Original surface elevation at $80 \mathrm{Ma}$ is shown arbitrarily at $0 \mathrm{~km}$, before accumulation of Laramide volcanic pile and upper-crustal thickening due to Laramide reverse faulting. Inferred paleodepths of Laramide igneous and hydrothermal systems reflect this composite column. Based on previous work by the U.S. Geological Survey and the University of Arizona, with new mapping (of alteration and faulting) and geochronology by University of Arizona faculty, postdoctoral fellows, and students. 
est events. Although the interpreted geology differs markedly from earlier versions (Howard and Foster, 1996), note that the new cross section appears to have regional-scale structural elements which are strongly reminiscent of those shown in line drawings of old seismic sections through the area (for example, Naruk and others, 1986, fig. 6). As the cross section illustrates, the size of the associated syntectonic basins and the volume of associated sediment may be deceptively small. Our preliminary interpretation of the geology, involving partial spatial superposition of temporally distinct half-grabens, implies an opportunity to preserve various paleodepths of magmatic-hydrothermal systems during concurrent faulting and tilting (as opposed to the case of top-down erosion in a conceptual horst-and-graben geometry).

The extensiveness of newly mapped hydrothermal alteration in the area implies that (1) eroding magmatic-hydrothermal systems have been the sources of clasts and dissolved constituents to the sedimentary deposits that form local ground-water aquifers, and (2) natural weathering of the systems is dispersing constituents to present-day surface waters.

\section{Ray-Granite Mountain-Copper Butte}

\section{Stop 1-8: Overlook of the Ray Mine}

This stop is at the Asarco, Inc., overlook on the west side of the pit (200 m east of Arizona Highway 177). The overlook gives a good perspective on the bigger picture of the distribution of porphyry systems and of related alteration and weathering products in the Ray area and vicinity. In addition, we can address some of the regional structural issues that play an important, but poorly constrained, role.

To the east lie the Dripping Spring Mountains (fig. 1-1), largely upper Precambrian siliciclastic sedimentary rocks of the Apache Group and intruded diabase sills and overlying Paleozoic carbonate rocks. The Troy, Chilito, and Christmas deposits lie off to the southeast more or less along the axis of the range. To the west is Granite Mountain, with outcrops of parts of the Granite Mountain pluton and Precambrian Pinal Schist basement. To the north is Teapot Mountain, capped by 18.6-Ma dacite of the Apache Leap Tuff that overlies mid-Tertiary Whitetail Formation (an undifferentiated equivalent to the San Manuel and Cloudburst Formations north of the Gila River; Dickinson, 2001).

Within a few kilometers to the north, west, and south of the Ray Mine, mid-Tertiary sedimentary deposits are tilted from $60^{\circ}$ to more than $90^{\circ}$ (fig. 1-12); however, most bedrock in the Dripping Spring Mountains immediately to the east dips less than $20^{\circ}$. Some mid-Tertiary sedimentary deposits on the west flank of the Dripping Spring Mountains (tan-light-brown rocks in northeast pitwall) dip gently west and east and appear to be "folded." The relations of the various Tertiary sedimentary rocks in the area to each other, to the underlying bedrock (remember: tilted sedimentary rocks record only postdepositional tilting of bedrock!), and to the more regional tilting history are complex and poorly understood here.

The mid-Tertiary structural setting here is complicated by pre-Laramide to early Laramide thrust faulting and folding, as well as by both down-to-the-west and down-to-the-east normal faulting that has redistributed the alteration zones of the Ray deposit. East of the overlook, in the bottom of the main pit, rocks in the footwall of the low-angle Emperor Fault are biotitized, with primary copper mineralization hosted in diabase, porphyry, and sedimentary wallrocks of the Apache Group. To the north-northwest, in the west-pit area and on Last Turn Hill (foreground), rocks in the hanging wall of the Emperor Fault are sericitized Pinal Schist, with significant secondary mineralization. Thus, (1) the Emperor Fault displaces the alteration zoning of the original deposit, (2) no apparent compressional deformational features are expressed in the porphyry system, and (3) the fault places older over younger rocks. This situation is a bit of a conundrum, but it may be explainable by an early, postmineral normal fault cutting a premineral thrust fault or fold and subsequently cut by later normal faults and rotated into its present position. In addition to probably at least two sets of down-to-the-west normal faults and related rotation (analogous to that seen in the Ripsey-Kelvin area earlier), the down-to-the-east faulting here resulted in at least minor westward tilting (although the age relations between these events are as yet unclear).

The result of this complex faulting and tilting is a chaotic structural redistribution of the original porphyry system. For example, in addition to the alteration described above, on the east flank of Granite Mountain (to the west), fine- to mediumgrained equigranular granodioritic rocks are cut by quartz+Kfeldspar+chalcopyrite (oxidized to $\mathrm{Cu}$-limonite) veins and greisen veins - a deeper part of the hydrothermal system that is at a higher elevation than the sericitization in the west pit and on Last Turn Hill. Immediately adjacent to Last Turn Hill (to the north) is an exposure of a late-stage porphyry (Teapot Mountain Porphyry) that is weakly propylitized and $\mathrm{K}$-silicate altered (also deeper to lateral levels of the system?). Immediately south of Sonora Hill (foreground to south), sericitized schist is juxtaposed against weakly mineralized, strongly biotitized diorite. On a regional scale, the sericitized rocks between Copper Butte and Cochran (6-14 km west-southwest of Ray) may be displaced sections of rocks in the west-pit area. Finally, underneath a significant thickness of primary mineralization in the Ray area, another zone of secondary mineralization underlain by more primary mineralization has been observed.

These complex juxtapositions of varyingly altered and mineralized (as well as unaltered and unmineralized) rocks make mine planning, reserve estimation, ore control (predicting orewaste boundaries and anticipating dilution effects), production planning (mill throughput), and overall economic assessment of the deposit extremely difficult. Moreover, until all important structures have been identified and the resulting displacement of rocks has been determined, undiscovered mineralized parts of the deposit may yet be found. Locating and predicting structures in 


\section{A. Modern Cross Section}
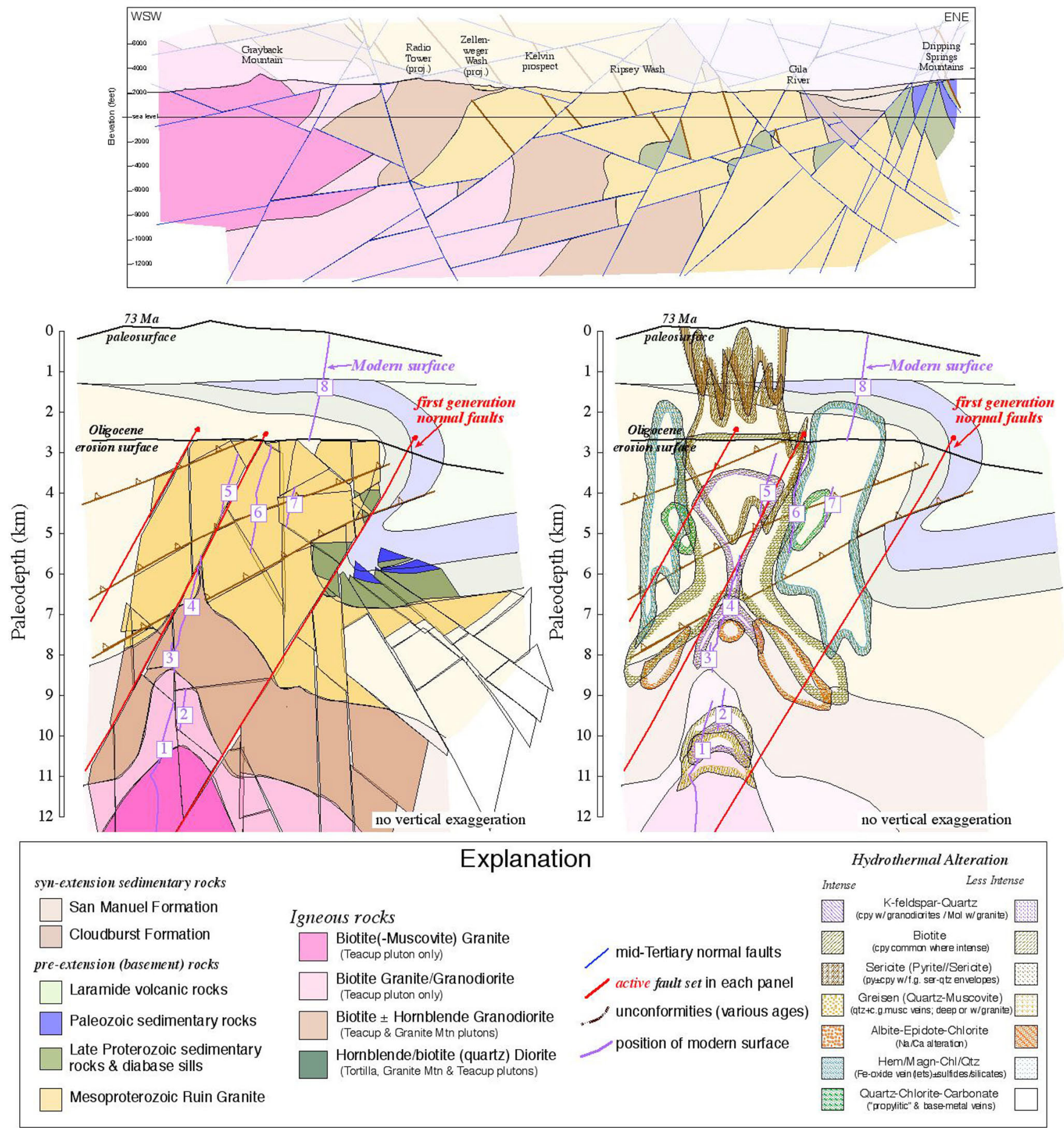

Figure 1-11. Modern geologic cross section (A) and palinspastic reconstruction (B) of the Grayback-Kelvin-Riverside area, northern Tortilla Mountains, south-central Arizona (figs. 1-1, 1-2). By Eric Seedorff, on the basis of new geologic and alteration mapping and structural interpretation that provide key evidence for how to reassemble the system. Numbered segments in figure 1-11B increase from west to east across section. No vertical exaggeration. 
the mine area requires a synthesis of data at both the regional and mine scales and, generally, working backward by identifying and restoring progressively older faults.

Erosional and depositional processes (mostly resulting from structural displacement and exposure of parts of the porphyry system) have also redistributed a significant amount of altered material from the original Ray porphyry system. Several exotic copper deposits of varying size and grade have resulted from these processes, including the Tertiary Copper Butte deposit (stop 1-9), the Tertiary Pioneer-Alabama deposit (southwest of Copper Butte, fig. 1-7), and the Holocene Mineral Creek deposit (Phillips and others, 1970) about $1 \mathrm{~km}$ southeast of the overlook (which was discovered and mined out during expansion of the Pearl pit). These deposits represent a significant dispersion of mineral components in the paleosurface environment.

\section{Stop 1-9: Copper Butte}

The purpose of this stop is to start some detailed discussions of weathering and dispersion, to be addressed by task 4 of the project. Copper Butte, where probable early Miocene conglomerate of the Whitetail Formation is copper mineralized, is an interesting example of paleodispersion from a porphyry copper deposit (presumably, the Ray). Some people may find it surprising that this type of dispersion is not at all unique. Dispersion from the Laramide, Sonoran, porphyry copper deposits took place during several discrete intervals between Oligocene and Holocene time. Evidence for those intervals of dispersion can be observed in basin-fill conglomeratic and sedimentary rocks of those several ages at various places.

At Copper Butte, not everyone agrees on how the copper was dispersed. Some people favor a nearly purely mechanical dispersion, as in a debris flow of ore clasts; other people favor nearly the opposite: dispersion almost entirely within ground water, followed by authigenic precipitation as $\mathrm{Cu}$ oxide minerals. We suggest that you look for four specific items: (1) a clast of preexisting ore, in which the clast is cut by a stockwork of veinlets that contain copper minerals, (2) a clast with diagnostic leached capping textures within hematite or other "limonites"; (3) a clear example of a clast that has been replaced or partially replaced by copper minerals, and (4) a clear example of cementation or, at least, clearly grown-in-thematrix copper minerals. If you spot any of these items, show others. It's not as easy as it sounds!

Earlier workers (Phillips, 1976; Dickinson, 2001) considered Copper Butte to be an example of exotic copper deposits, like those described by Munchmeyer (1996) from Chile. Munchmeyer showed that the exotic deposits of Chile are a separable class, with a clear zonation from proximal hematitized- or leached-cap-clast gravel, through intermediate copper-wad-with-kaolinized-clast gravel, to distal chrysocollaplus-atacamite-with-unaltered-clast gravel (fig. 1-13). The same zones were also expressed in fracture fillings in bedrock subjacent to mineralized conglomerate. Some of the exotic deposits of Chile also have even more distal and overlying ferricrete and manganocrete zones. The source of ground-water ore fluids was a pyrite-bearing porphyry copper deposit undergoing supergene enrichment. The headwaters of a paleodrainage intersected the porphyry deposit during supergene alteration. Laterally advected, acidic $\mathrm{Cu}$-bearing solutions reacted with alluvial aquifer minerals, increasing the $\mathrm{pH}$ along the paleodrainage with greater distance from the source and causing copper mineralization and associated alteration. Over time, at any one place in the alluvial aquifer, the pore-fluid $\mathrm{pH}$ would decrease until the supply of acidic ore fluids was cut off. The evolution in time and space permits recognition of proximal, intermediate, and distal environments with respect to the source deposit.

As we saw earlier at stop 1-6, ferricrete and manganocrete also occur, with no clear association to exotic copper

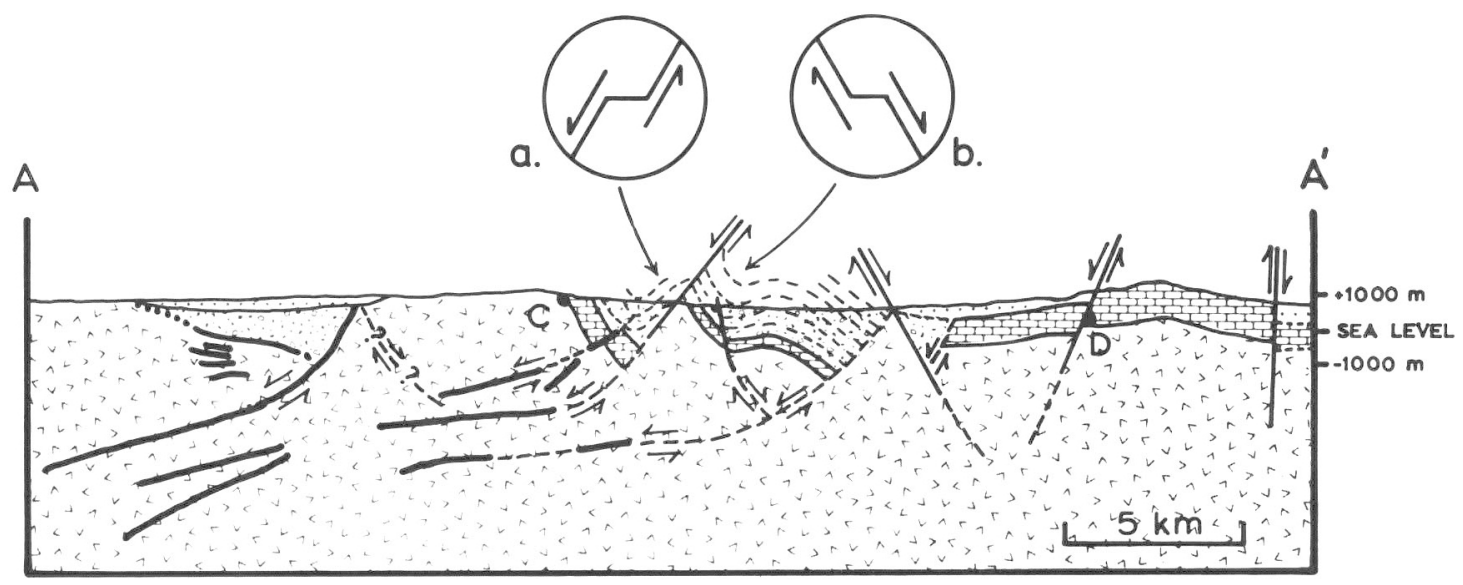

Figure 1-12. Schematic cross section across the northern Tortilla Mountains, south-central Arizona (figs. $1-1,1-2,1-5)$. Heavy solid lines in subsurface are strong reflections from east end of Anschutz seismic line AZ-18. Insets show kink-fold vergences in Ripsey Wash (a) and Hackberry Wash (b). Section is balanced in area and retrodeformable. Queried fault west of point $C$ is required by balancing. Amount of crustal extension calculated from cross section between points $C$ and $D$ is 39 percent. 


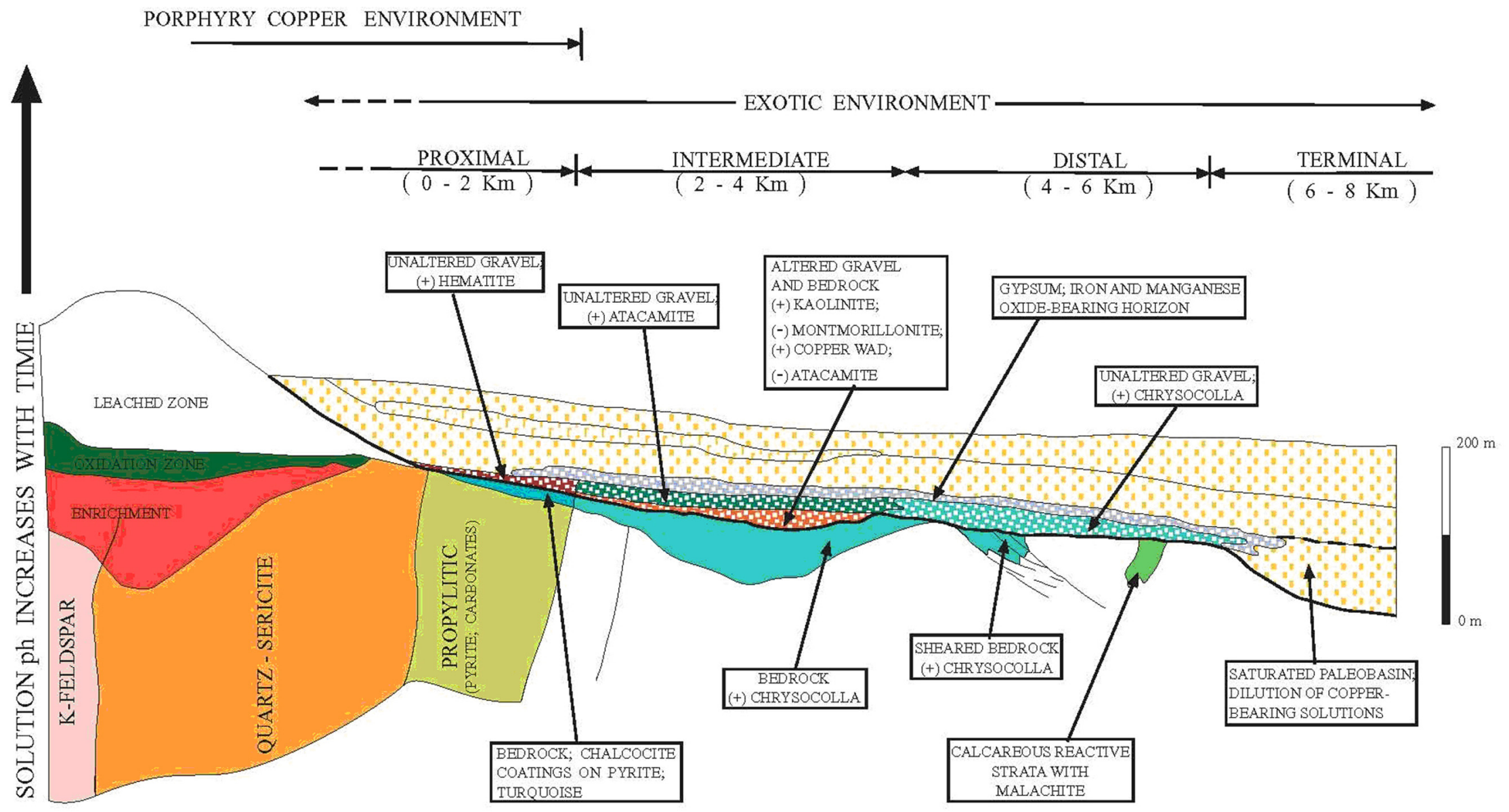

\section{pH INCREASES ALONG SOLUTION PATH}

Figure 1-13. Schematic model of exotic copper deposits, after Munchmeyer (1996). Copper mineral abundance or alteration intensity estimated to be minor (-), moderate $(-)$, or major (+). 
accumulations. We will see more examples of ferricrete and manganocrete as a special form of dispersal related to the Sonoran porphyry copper deposits in Pinal Creek (day 2) in a contaminated alluvial aquifer below the Miami-Inspiration porphyry deposits. At Pinal Creek, various parts of the contaminated aquifer may represent a modern exotic deposit of the type represented in figure 1-13 in the process of forming. The analogy is probably imperfect but informative.

\section{Superior-Pinto Valley Area}

Two stops in the Superior area along U.S. Highway 60 from the town of Superior to Pinto Valley (fig. 1-1) highlight the cyclicity of copper-mining life cycles and associated technical issues. Several major expansions, modernizations, and closures occurred, but the biggest potential economic prize was not located until more than a century after mining began. These stops also illustrate the diversity of host rocks, alteration types, and opaque-mineral assemblages and metal grades in adjacent porphyry deposits, the extreme variation in the As content of ores in adjacent systems, another opportunity to view the deep root zones of a Laramide hydrothermal system, examples of how Laramide and Tertiary structural complexities and postmineral cover conceal ore bodies, and the physical and chemical dispersion of Laramide systems during Tertiary weathering and crustal extension.

Further geologic and geochemical understanding of the natural occurrence of arsenic in porphyry copper systems, for example, may benefit the broader public. Certain members of the project are members of an informal "Arsenic Working Group," whereby they have an opportunity to convey Earthscience information to biological scientists and public-health officials.

\section{Stop 1-10: Overlook of the Town of Superior}

The town of Superior is located in the heart of the Pioneer (Superior) Mining District. Short and others (1943) and Hammer and Peterson (1968) summarized its geology and history. Total production from the district totals 24.2 million metric tons (26.7 million tons) of ore with an average grade of 4.90 weight percent $\mathrm{Cu}$, yielding about 1.13 million tons ( 2.5 billion $\mathrm{lb}$ ) of $\mathrm{Cu}$. The district formed around the Silver King Mine, which produced high-grade, supergene-enriched silver ore during the final quarter of the 19th century. A nearby mine, the Silver Queen, had only minor production during that period. William Boyce Thompson, while developing the Inspiration Copper Mine at Miami, purchased the Silver Queen Mine in 1910 and founded the Magma Copper Co. (Thompson also was one of the founders of Newmont Mining Corp. and created the famous desert arboretum that is located a few miles west of Superior.) In 1913, a major ore shoot was discovered on the Magma vein (part of the Silver Queen Mine), which displays strong mineralogic and metal zoning and is noted for the enargite richness of its ores (Gustafson, 1961; Hammer and Peterson, 1968). The Cu-Zn-Ag-bearing vein, adjacent $\mathrm{Cu}$ mantos, and distal Au-bearing silica-hematite bodies are members of the class of Cordilleran, porphyry-related, base-metal lodes that include the veins at Butte, Montana, and Chuquicamata, Chile, except that the ores of the Magma Mine are hosted primarily by Proterozoic strata, diabase sills, and overlying Paleozoic carbonates and clastic rocks (Einaudi, 1982; Paul and Knight, 1995; Friehauf, 1996; Friehauf and Pareja, 1998). The Magma Mine produced from 1914 to 1965 , feeding a concentrator and adjacent smelter (which ceased operation many years ago). Over time, production shifted from the deep parts of the vein to the mantos and extended farther eastward and southward beneath the cliff-forming Apache Leap Tuff (18.6 Ma). The smelter stack still stands, although the rest of the smelter and adjacent concentrator have been dismantled. Site reclamation continues.

East of Apache Leap, on the top of Oak Flat, lies the No. 9 Shaft complex, which was established during an expansion and modernization program in the early 1970 s associated with exploitation of the mantos. In 1976, Asarco, Inc., discovered a deep porphyry copper deposit (fig. 1-14), dubbed the Superior East deposit, hosted by porphyry cutting the Precambrian Pinal Schist and located entirely beneath the Apache Leap Tuff, 6 $\mathrm{km}$ due east of the town of Superior (Sell, 1995). The program that developed the manto ore bodies and led to installation of the No. 9 Shaft made an unexpected geologic discovery: a thick section of Mesozoic andesitic volcanic and sedimentary rocks, similar to those exposed near the Christmas-Reed Basin area (figs. 1-1,1-2), that occurs entirely beneath the Apache Leap Tuff. The Mesozoic rocks do not extend as far eastward as the Superior East deposit. Because these Mesozoic rocks are probably bounded by Laramide(?) faults on their northern and southern margins and mineralization associated with the Magma Mine occurs along the northern margin, Newmont Mining Corp. initiated a program to locate the southern margin and to explore for new ore bodies adjacent to it.

The Magma Mine was put on care and maintenance in 1982, owing to low copper prices, and exploration ceased. Newmont Mining Corp.'s subsidiary, the Magma Copper Co., was spun off as an independent company in 1987. The Magma Copper Co. reopened the Magma Mine in 1990 under the new name of Superior. The company mined the manto ore bodies with new underground methods, shipping concentrates to the San Manuel smelter. Given the short reserve life, the Magma Copper Co. resumed exploration in 1991, beginning with concepts that Newmont Mining Corp. had used previously. In late 1994, a new porphyry copper system was discovered in the Mesozoic block (that is, between the north and south boundaries), several kilometers south of the No. 9 Shaft and several kilometers west of the Superior East deposit. The intercepts, the history of the discovery, and the geology were summarized by Manske and Paul (2002).

The discovery was made by a long corehole collared from underground that cut the upper levels of the system and contained high-grade vein intercepts within a "sea" of low-grade 
mineralization. The first major intercept of "disseminated" or "stockwork" mineralization and the first observation of potassic alteration in the system occurred in fall 1995, also in a long hole drilled from underground. BHP Copper Inc. bought the Magma Copper Co. in January 1996 and over the next several years obtained four additional major intercepts during the advanced exploration and early development stages of the project, two each from long coreholes collared underground and deep coreholes collared from the surface. Any deep ore body faces challenging technical issues, and the program was eventually terminated during a period of low copper prices.

The Magma Mine was allowed to flood in January 2002, and the deposit was eventually farmed out. Kennecott (Rio
Tinto), which is the current operator in a joint venture with BHP Billiton, is drilling several deep holes from the surface. Although the system was originally named the "Magma Porphyry deposit" (in reference to the historical Magma Mine), Kennecott now refers to it as the Resolution deposit.

The salient points related to the Resolution deposit and its discovery are that (1) the system is a porphyry copper deposit with significant molybdenum credits and negligible gold; (2) the system contains the complete range of alteration-mineralization environments from advanced argillic to sericitic to intermediate argillic, from potassic to propylitic, and from igneous-hosted to calc-silicate hornfels and skarn; (3) the deposit contains ore-grade copper intercepts in advanced
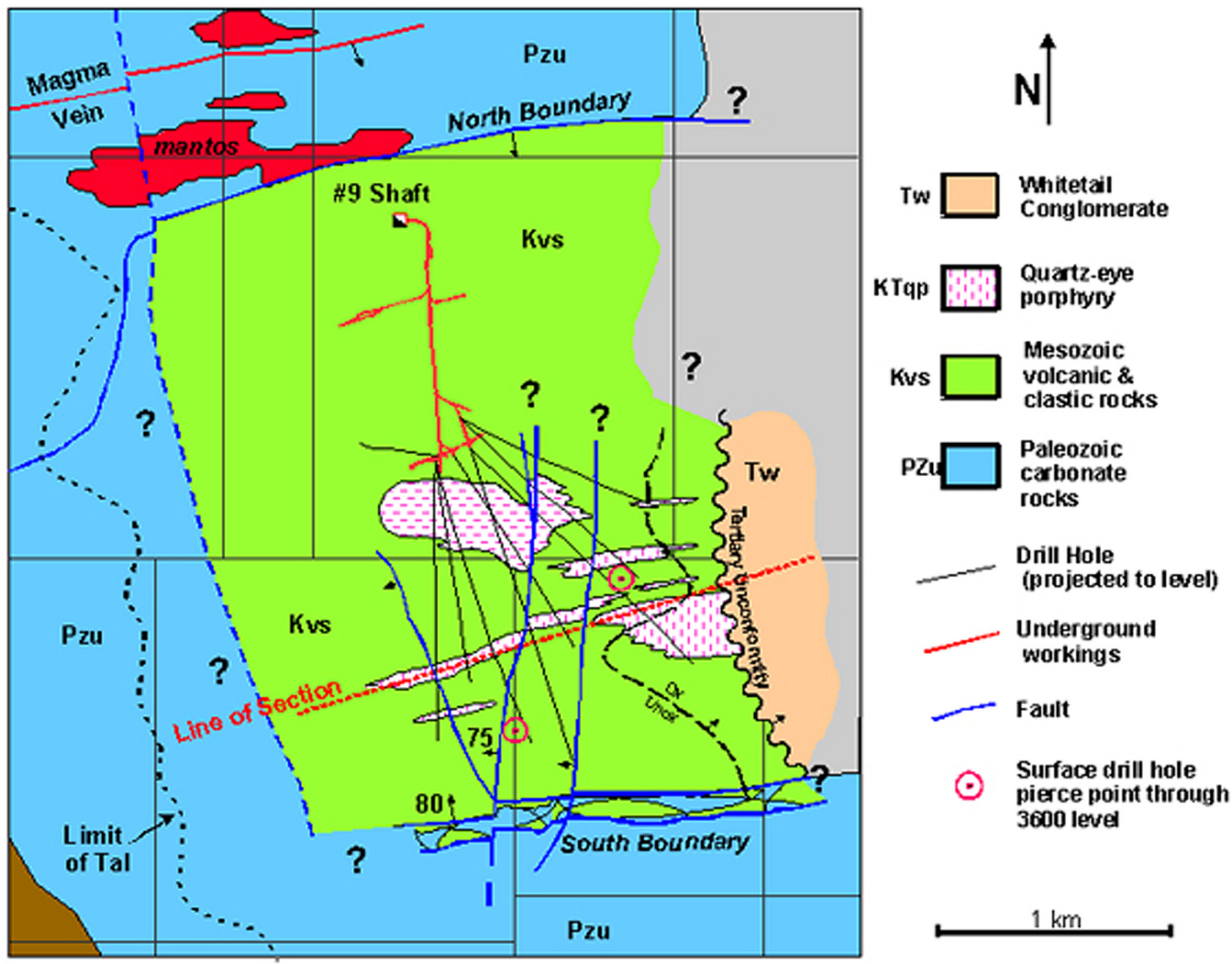

After S. L. Manske, pers. comm., 1999

Figure 1-14. Plan view of the Magma Mine, south-central Arizona (figs. 1-1, 1-2, 1-5), showing geologic relations at 3,600$\mathrm{ft}$ level, distribution of materials along the Magma vein/replacement system, and scale of recently (1994) discovered, fully hidden, large, high-grade Resolution (Magma) porphyry copper deposit. Although As content was quite high in the Magma vein system, it is very low in the porphyry deposit. From BHP Inc., courtesy of Eric Seedorff. 
argillic, sericitic, potassic, and hornfels/skarn alteration; (4) although the principal opaque-mineral assemblage in potassic alteration may be chalcopyrite (generally without magnetite or bornite and possibly without pyrite), sericitic and advanced argillic assemblages contain abundant bornite-pyrite and digenite-pyrite but no hypogene covellite; (5) the deposit may be distinct from the Superior East system, although in 1999 a structural offset could not be ruled out; (6) the deposit appears to be distinct from the Magma vein and manto system, with a barren gap between; (7) despite its advanced argillic alteration and abundant bornite and digenite, the deposit appears to be remarkably free of arsenic - in stark contrast to the neighboring system that includes the Magma vein; (8) "exotic" copper (primarily as native copper, also totally hidden under the Apache Leap Tuff) is abundant in the Whitetail Formation laterally adjacent to and hydrologically downgradient of the hypogene system, owing to chemical dispersion of copper during one or more cycles of weathering of the upper part of the Resolution system and (or) other systems in the area; and (9) although the size and average grade of the deposit have not been determined, it is almost certainly the porphyry deposit with the highest average hypogene copper grade ever discovered in Arizona, after more than a century of mining in the area and a half-century of intensive modern exploration.

\section{Stop 1-11: Overlook of the Pinto Valley Mine at the Exposure of Schultze Granite near Pinto Creek}

This stop is on U.S. Highway 60, a few hundred meters west of the bridge crossing Pinto Creek, where the Pinto Valley minesite is visible in the distance to the north and a roadcut exposes Schultze Granite on the south. (Beware of traffic!) This area is generally regarded as the west end of the GlobeMiami Mining District (Peterson, 1962), the major subject of the tour on day 2, which offers insights into the geology, historical production, physical dispersion, and environmental aspects of the porphyry copper life cycle in the Southwest.

Although the district is commonly regarded as only slightly rotated (Wilkins and Heidrick, 1995), its geology is complex, and the crust in the area probably is extended 100 percent or more. For example, the Pinto Valley deposit is bounded on three sides by major faults (Breitrick and Lenzi, 1987). Extensional structures also affect hydrologic and mine-production issues, such as slope stability and ore control. If land-use and operating issues in the district were less involved, further understanding of its structural complexity could lead to discovery of new ore bodies, because the postore cover is extensive.

Mining began in the Pinto Valley area with exploitation of a supergene-enriched blanket on the flank of Porphyry Mountain by the Castle Dome Mine. The mine, which was a World War II-era project owned and operated by a subsidiary of the Miami Copper Co. (Peterson and others, 1946, 1951), produced 41 million tons of ore with an average grade of 0.62 weight percent $\mathrm{Cu}$ (Breitrick and Lenzi, 1987). The hypogene part of the system, which has relatively low copper grades $\sim 0.4$ weight percent $\mathrm{Cu}$ ) and low molybdenite credits ( $\sim 0.01$ weight percent Mo), was later developed by an oil company, the Cities Service Co., during a period of high copper prices (Li and Carter, 1975). The deposit, which is hosted principally by Proterozoic granite, exposes extensive potassic alteration and minor sericitization (essentially, the deep levels of the hydrothermal system), and the principal opaque-mineral assemblage is chalcopyrite-pyrite. The copper grade is remarkably uniform.

During a period of low copper prices, the Pinto Valley deposit was sold to Newmont Mining Corp., which maintained it as an independent division. Newmont later spun the division off into the Magma Copper Co. in 1987 during another period of low prices when the corporation was being pressured to dispose of its nongold assets. Upon purchase of the company by BHP Copper Inc. in 1996, Pinto Valley became a part of BHP Copper Inc. (now BHP Billiton). Several hundred million tons of ore has been mined at the deposit, and reserves and resources are highly sensitive to operating costs and assumed copper price. Although the open pit has been on care and maintenance for about 5 years, leaching of dumps that contain principally low-grade hypogene sulfide mineralization and minor copper production by solvent extraction and electrowinning (SX/EW) continues.

To the southeast along Pinto Creek, Cambior Inc. attempted to develop the Cactus Carlota deposit but faced difficult permitting issues. The "Cactus breccia" in the Cactus Carlota deposit has been described as a sedimentary breccia that was produced during extensional unroofing of a porphyry copper deposit in the district, which would represent physical dispersion of part of the system during extensional faulting, with possible analogies to the Copper Butte deposit seen earlier today.

Schultze Granite exposed in the roadcut is cut by numerous sheeted quartz veins with K-feldspar envelopes and local glassy limonite after chalcopyrite, as well as sparse greisen muscovite veins. This part of the Schultze Granite is inferred to be the root zone of one of the porphyry copper system(s) in the Globe-Miami or Superior district. The granite resembles the intermediate levels of the Granite Mountain pluton west of Ray more than it does the Teacup pluton.

\section{Day 2: Pinal Creek Basin Near Globe, Ariz.}

The Pinal Creek basin near Globe, Ariz. (fig. 2-1), has been an area of large-scale copper mining since the 1880s. Mining began in the late 1870s with the extraction of silver ore from the hills north of Globe (Ransome, 1903). Copper mining began in the basin in 1882 with the development of underground mines north of Globe. Later, large porphyry deposits were developed north of Miami, first using underground methods, and then using open-pit methods beginning in 1948. 
Ground-water contamination was first recognized in the basin in the 1930s. Acidic drainage in the basin has resulted from various sources, including oxidation of sulfide minerals, seepage from unlined surface-water impoundments, and other activities. At present, a ground-water plume extends in stream alluvium from the mined areas to Inspiration Dam (fig. 2-1), at which point the aquifer is truncated by less permeable volcanic rocks. Geologic controls sustain a 6-km-long perennial reach of partially neutralized streamflow above Inspiration Dam.

Several remedial activities are currently being carried out by the Pinal Creek Group, an alliance composed of BHP Copper Inc., Phelps Dodge Miami, Inc., and the Inspiration Consolidated Copper Co., including source removal and containment, pumping and treatment of contaminated ground water, and return of treated water to the streambed of Pinal Creek. Concurrently, process-oriented research on the physical and chemical controls on the movement and fate of contaminants in ground water and surface water is being done collaboratively by the USGS, the University of Arizona, the Arizona State Uni- versity, and the Scripps Institution of Oceanography through a combination of field, laboratory, and modeling studies.

\section{Stop 2-1: Old Dominion Mine}

The Old Dominion Mine, which was established in 1882, for decades was one of the largest mines in the Globe-Miami area (fig. 2-1). Upper levels contained rich oxidized ore bodies, and lower levels contain sulfide ore. The mine is of interest from a hydrologic standpoint because it was plagued by water problems for most if its active life. Workings at the 12 th level on the west side of the mine penetrated water that was moving from the basin fill through fractured dacite into the mine; more than 3 million gal/day had to be pumped to keep the mine in operation. Water also was penetrated in the 18th level as the mine was extended eastward beneath the hills north of Globe. Water here occurred mainly in shale and quartzite formations associated with the Old Dominion Vein Fault (Peterson, 1962; Beckett, 1917); this water was warmer

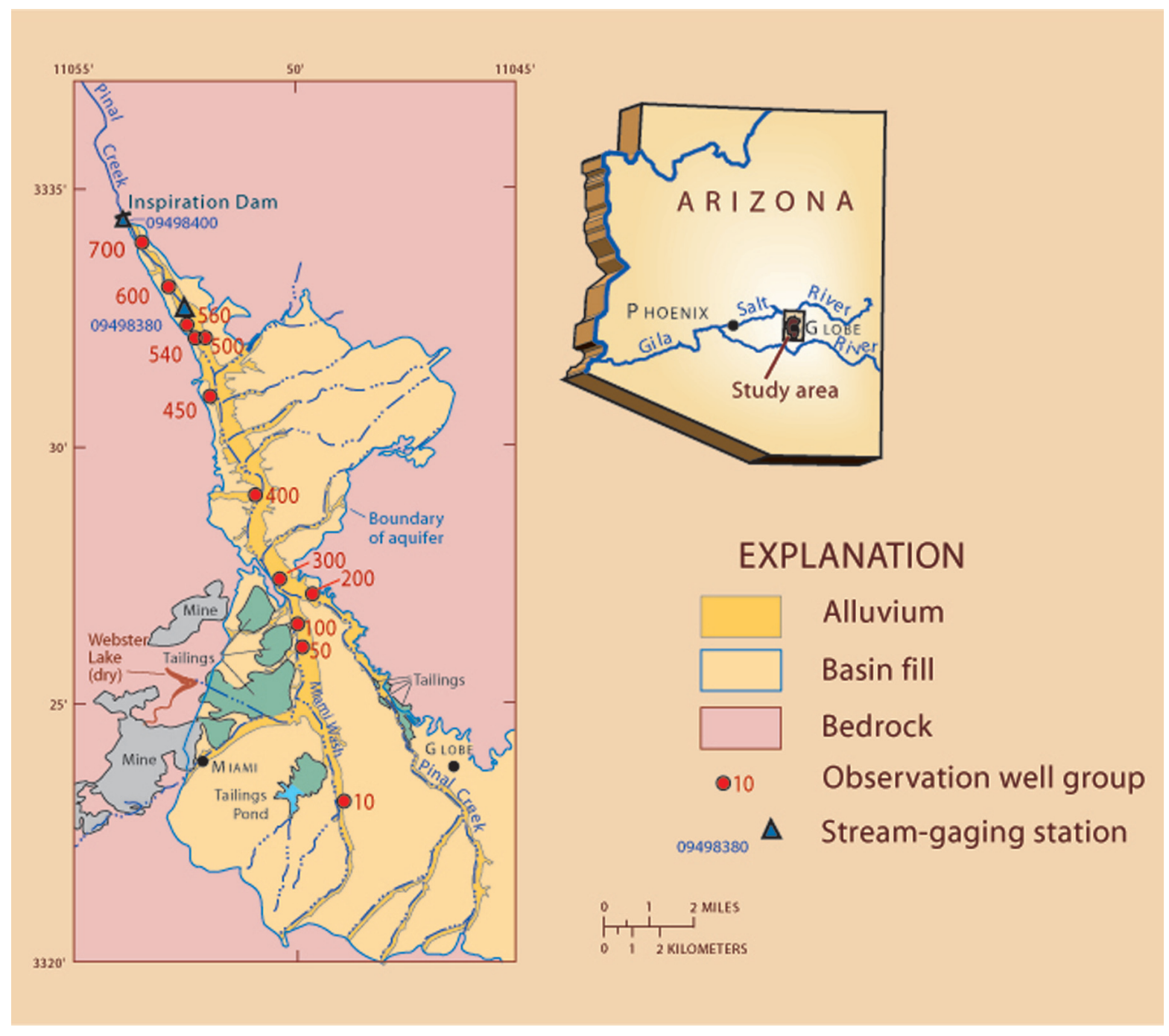

Figure 2-1. Generalized map of the Pinal Creek basin near Globe, Ariz. (figs. 1-1, 1-2). 
and more mineralized than that in the western part of the mine. The mine, which was closed in 1931 and never reopened, was a source of water for mining and other uses for many years.

\section{Stop 2-2: Overlook of the Valley from the Holiday Inn Express Parking Lot}

The tailings piles to the west are about $60 \mathrm{~m}$ tall and extend about $3 \mathrm{~km}$ along Miami Wash, which begins at the south end of the golf course, where Bloody Tanks Wash from the west joins Russell Gulch from the south (fig. 2-1). Miami Wash lies on a flat surface of unconsolidated alluvium, underlain by basin fill. Stream alluvium and basin fill compose the regional aquifer of the basin. The basin fill, also called the Gila Conglomerate, is exposed in hills on both sides of the valley. To the south, the Pinal Mountains, which rise to about 2,400 m, are a major source of recharge to the aquifer. To the north, the aquifer becomes constricted laterally and at depth and pinches out near the intermediate skyline, which is rimmed by Tertiary volcanic rocks. The farthest skyline is the Sierra Ancha Mountains north of the Salt River, about $50 \mathrm{~km}$ away.

\section{Stop 2-3: Phelps Dodge Mining Land Office}

Meet Jay Spehar and James Clark for safety orientation. Proceed to mine operations.

\section{Stop 2-4: BL Open Pit}

Quaternary through Tertiary Gila Conglomerate caps the upper west wall of the BL open pit, where 30 to $60 \mathrm{~m}$ of welded Apache Leap Tuff sits over most of the mineralized zone. All of the ore occurrences in the BL open pit are in Precambrian Pinal Schist; the main ore minerals are chrysocolla and chalcocite. The north half of the ore body is shifted more than $300 \mathrm{~m}$ along a right-lateral fault. All of the Pinal Schist in the west wall is in a landslide megabreccia.

\section{Stop 2-5: Willow Springs Solvent-Extraction Plant}

$\mathrm{Cu}$-bearing solutions from heap-leaching operations are further processed here. An organic solvent is used to separate the copper from other solutes. The copper is then stripped from the organic solvent by using sulfuric acid.

\section{Stop 2-6: Dry Bed of Webster Lake}

Webster Lake, formed initially by a slumped tailings pile in about 1941 (Timmers, 1986), held a combination of natural runoff and mine-process water until 1988, when the lake was drained. During the 1980s, the lake water had a pH of about 2.6 and contained about $30 \mathrm{~g}$ of $\mathrm{Fe}$ (II) sulfate and other metals per liter.

\section{Stop 2-7: Overlook of the Smelter}

The smelter operates as a toll smelter. Feedstock is imported from the Sierrita, Bagdad, and other mines. The mill here was shut down in January 1986.

\section{Stop 2-8 (Lunch Stop): Overlook of the Valley from the Edge of the Tailings Pile}

A major tailings-reclamation project was undertaken in the late 1980s to reduce tailings erosion and windblown dust. These tailings were capped with a layer of Gila Conglomerate (basin fill) and planted with grasses for stabilization. Cows were grazed on the tailings from time to time to fertilize the grass and promote vegetation growth on the cover.

\section{Stop 2-9: Bixby Road Seepage Ditch and Wellsite}

During a period of high ground-water levels in the mid1980s, acidic water was discharged into this ditch between the railroad tracks and Bixby Road. The Gila Conglomerate is about $100 \mathrm{~m}$ thick here, in comparison with more than 1,200 $\mathrm{m}$ about $3 \mathrm{~km}$ to the south. As ferrous iron oxidized in the ditch, Fe(III) hydroxide precipitated, and other metals, such as copper, cobalt, nickel, and zinc, adsorbed onto the iron. In August 1985, the $\mathrm{pH}$ of the stream water decreased from about 5.5 at this point to 3.2 (Eychaner and others, 1989) where flow in the ditch rejoins Miami Wash $1 \mathrm{~km}$ downstream and returns to the aquifer. The ditch was dry from about 1986 to 1992 but flowed again in late winter and spring 1993, when the $\mathrm{pH}$ of the stream water was about 6.2 (fig. 2-2).

Wellsite 100 is about $0.15 \mathrm{~km}$ west and across the highway, near a large chainlink gate. Here, steel casings 1.5 $\mathrm{m}$ deep protect the 10-cm-diameter polyvinyl chloride (PVC) wells that range in depth from 11 to $49 \mathrm{~m}$ below the land surface. In 2001, the $\mathrm{pH}$ of ground water in the alluvium and upper $15 \mathrm{~m}$ of basin fill was 3.9 , and its metal contents were $66 \mathrm{mg} \mathrm{Fe}, 48 \mathrm{mg} \mathrm{Cu}$, and $0.6 \mathrm{mg}$ Ni per liter. At about 50-m depth below the land surface (in basin fill), the $\mathrm{pH}$ of the ground water was about 7 , and its metal contents were at or below minimum reporting levels (see data for well 101 at wellsite 100 , fig. 2-3).

\section{Driveby 2-10: Water-Treatment Plant}

In November 1999, a water-treatment plant began operation, removing dissolved $\mathrm{Cu}, \mathrm{Mn}, \mathrm{Al}, \mathrm{Fe}, \mathrm{Zn}$, and other 
metals from contaminated ground water, using a two-stage limetreatment process. The plant is designed to handle as much as $6,500 \mathrm{gal} / \mathrm{min}$. Treated water is filtered, neutralized, and returned to the creekbed on the downstream side of the barrier wall.

\section{Stop 2-11: Lower Pinal Creek Well Field}

A total of 18 extraction wells with a total capacity of $6,500 \mathrm{gal} / \mathrm{min}$ were installed during the late 1990 s to remove contaminated ground water and prevent the breakthrough of dissolved metals to the perennial reach of Pinal Creek. During normal operations, ground water is withdrawn at a rate of approximately 3,000 gal/min. In 2001, the $\mathrm{pH}$ of ground water from a monitoring well at the well field was 4.5, and its metal contents were $48 \mathrm{mg} \mathrm{Fe}, 2.4 \mathrm{mg} \mathrm{Cu}$, and $0.4 \mathrm{mg}$ Ni per liter.

\section{Stop 2-12: Barrier Wall}

In winter 2000-1, an impermeable barrier wall was installed just downstream from the well field. The wall spans the inner part of the valley and extends vertically to the alluvium/basin fill contact, at about 34-m depth. The wall is about
$1 \mathrm{~m}$ thick and composed of a three-component mixture of fine soil and clay, imported bentonite, and cement.

\section{Stop 2-13: Outfall Structure}

Treated water is returned to the creek by way of an outfall structure located just downstream of the barrier wall. In December 1999, the pH of treated water in the creek just below the outfall was about 7 , and its metal contents were less than $1 \mathrm{mg} \mathrm{Mn}$ and less than $0.01 \mathrm{mg} \mathrm{Co}, \mathrm{Ni}$, and $\mathrm{Zn}$ per liter.

Before the barrier wall and outfall structure were constructed, perennial flow commenced just downstream of the barrier wall. However, the location of the head of flow was not static in the past but migrated in response to recharge events and other changes to the hydrologic system. After the recharge event associated with the 1993 flood, the beginning of perennial flow moved upstream to the vicinity of the H\&E Ranch and gradually migrated downstream over the next several years.

\section{Driveby 2-14: H\&E Ranch Headquarters}

The H\&E Ranch breeds Brahman, Braford, and Hereford beef cattle and thoroughbred horses on about 250 ha of land

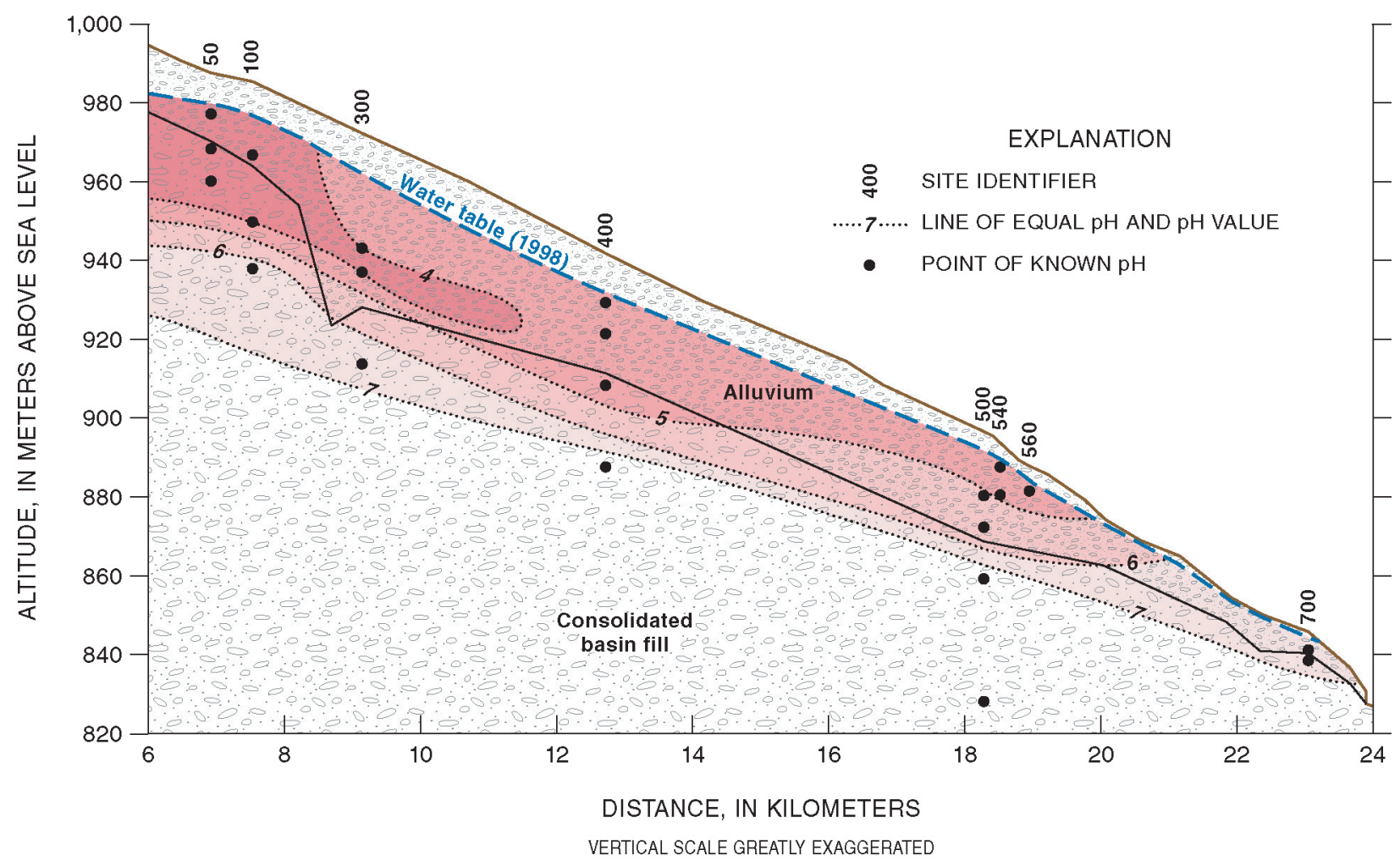

Figure 2-2. Cross section of aquifer at Bixby Road seepage ditch near Globe, Ariz. (figs. 1-1, 1-2), showing distribution of $\mathrm{pH}$ in aquifer in 1998. Line of section approximates principal ground-water flowline from site 50 (in the Kiser Basin) to Inspiration Dam. 
in the valley plus extensive areas leased from the U.S. Forest Service and copper companies.

\section{Stop 2-15: Pinal Creek at the Pringle Well Field and Pump Station}

The Pringle well field withdraws about 1,000 gal/min for use as process-makeup water at the Phelps Dodge Miami operations. Old drilling logs reported about $20 \mathrm{~m}$ of sandstone overlying conglomerate. West of the channel, basin fill crops out as lakebeds. The rounded boulders higher on the west slope are composed of Tertiary welded tuff, which truncates the aquifer about $2 \mathrm{~km}$ to the north. Stream discharge has been gaged at that point since 1980, and water samples are collected periodically. Mn oxides and carbonates have been actively deposited in the channel here for more than a decade, but periodic high-flow events erode most of the deposits or bury them under other sediment.

The streambed at this site is underlain by hard crusts of Mn oxide. X-ray-diffraction and other analyses indicate that the crusts consist of various minerals, including pyrolu-

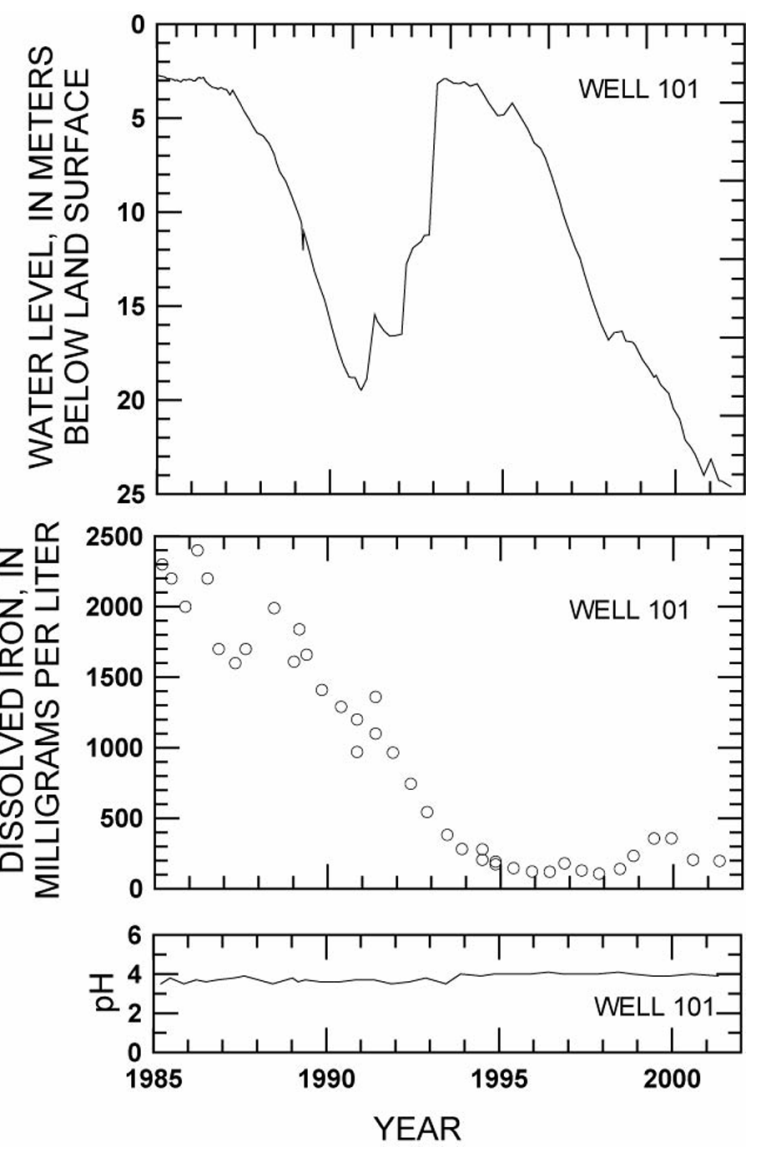

Figure 2-3. Water level $(A)$, Fe content $(B)$, and $\mathrm{pH}(C)$ from 1985 to 2002 in well 101 at Bixby Road seepage ditch near Globe, Ariz. (figs. 1-1, 1-2). site $\left(\mathrm{MnO}_{2}\right)$, rancieite $\left[\left(\mathrm{Ca}, \mathrm{Mn}^{2+}\right) \mathrm{Mn}_{4}^{4+} \mathrm{O}_{9} \cdot 3 \mathrm{H}_{2} \mathrm{O}\right]$, takanelite $\left[\left(\mathrm{Mn}^{2+}, \mathrm{Ca}\right) \mathrm{Mn}_{4}^{4+} \mathrm{O}_{8} \cdot \mathrm{H}_{2} \mathrm{O}\right]$, and 49 other mixed $\mathrm{Mn}$ oxide minerals (Lind and Hem, 1993; Kay and others, 2001). The attenuation of dissolved $\mathrm{Mn}, \mathrm{Ni}$, and $\mathrm{Co}$ in the perennial reach is controlled by concentrations of these metals in groundwater inflow, dilution by less contaminated or uncontaminated ground water, and biologically mediated reactions that drive the oxidation and precipitation of manganese in the streambed.

The series of photographs in figure $2-4$, taken about 4.5 $\mathrm{km}$ upstream of the Pringle Pump Station, illustrate the patterns of growth and partial removal since 1993, when recordhigh stream flow removed vegetation and Mn oxide crusts from the stream channel and deposited fresh sediment along much of its reach.

\section{References Cited}

Beckett, P.G., 1917, The water problem at the Old Dominion Mine: American Institute of Mining Engineers Transactions, v. 54, p. 35-66.

Bideaux, R.A., 1980, Famous mineral localities; Tiger, Arizona: Mineralogical Record, v. 11, no. 3, p. 155-181.

Breitrick, R.A., and Lenzi, G.W., 1987, Pinto Valley copper deposit, in Davis, G.H., and VandenDolder, E.M., eds., Geologic diversity of Arizona and its margins; excursions to choice areas: Geological Society of America Annual Meeting, 100th, Phoenix, Ariz., Field-Trip Guidebook (Arizona Geological Survey Special Paper 5), p. 260-265.

Brobst, D.A., and Pratt, W.P., 1973, United States mineral resources: U.S. Geological Survey Professional Paper 820, $722 \mathrm{p}$.

Cornwall, H.R., and Krieger, M.H., 1975a, Geologic map of the Grayback quadrangle, Pinal County, Arizona: U.S. Geological Survey Quadrangle Map GQ-1206, 2 p., scale $1: 24,000$.

Cornwall, H.R., and Krieger, M.H., 1975b, Geologic map of the Kearny quadrangle, Pinal County, Arizona: U.S. Geological Survey Quadrangle Map GQ-1188, 9 p., scale $1: 24,000$.

Creasey, S.C., 1950, Geology of the St. Anthony (Mammoth) area, Pinal County, Arizona, chap. 6 of Arizona zinc and lead deposits_-part 1: Arizona Bureau of Mines Bulletin 156, p. 63-84.

Creasey, S.C., 1965, Geology of the San Manuel Area, Pinal County, Arizona: U.S. Geological Survey Professional Paper 471, $64 \mathrm{p}$.

Dickinson, W.R., 1991, Tectonic setting of faulted Tertiary strata associated with the Catalina core complex in southern Arizona: Geological Society of America Special Paper 264, 106 p., scale 1:125,000. 
Dickinson, W.R., 1996, Geologic map of the Ripsey Wash area, Pinal County, Arizona: Arizona Geological Survey Contributed Map CM-96-B, 7 p., scale 1:24,000.

Dickinson, W.R., 1998, Facies map of post-mid-Miocene Quiburis Formation, San Pedro trough, Pinal, Pima, Gila, Graham, and Cochise Counties, Arizona: Arizona Geological Survey Contributed Map CM-98-A, 6 p., scale 1:24,000.

Dickinson, W.R., 2001, Geologic field guide to the Copper Butte area, eastern Pinal County, Arizona: Arizona Geological Survey Contributed Report CR-01-C, 16 p.

Einaudi, M.T., 1982, Description of skarns associated with porphyry copper plutons, in Titley, S.R., ed., Advances in geology of the porphyry copper deposits, southwestern
North America: Tucson, University of Arizona Press, p. 139-183.

Eychaner, J.H., Rehmann, M.R., and Brown, J.G., 1989, Chemical, geologic, and hydrologic data from the study of acidic contamination in the Miami Wash-Pinal Creek area, Arizona, water years 1984-87: U.S. Geological Survey Open-File Report 89-410, 105 p.

Force, E.R., 1997, Geology and mineral resources of the Santa Catalina Mountains, southeastern Arizona, (Monographs in Mineral Resource Science, no. 1): Tucson, University of Arizona Press, 135 p.

Force, E.R., and Dickinson, W.R., 1993, New work in the San Manuel and Mammoth districts (Pinal County, Arizona)-
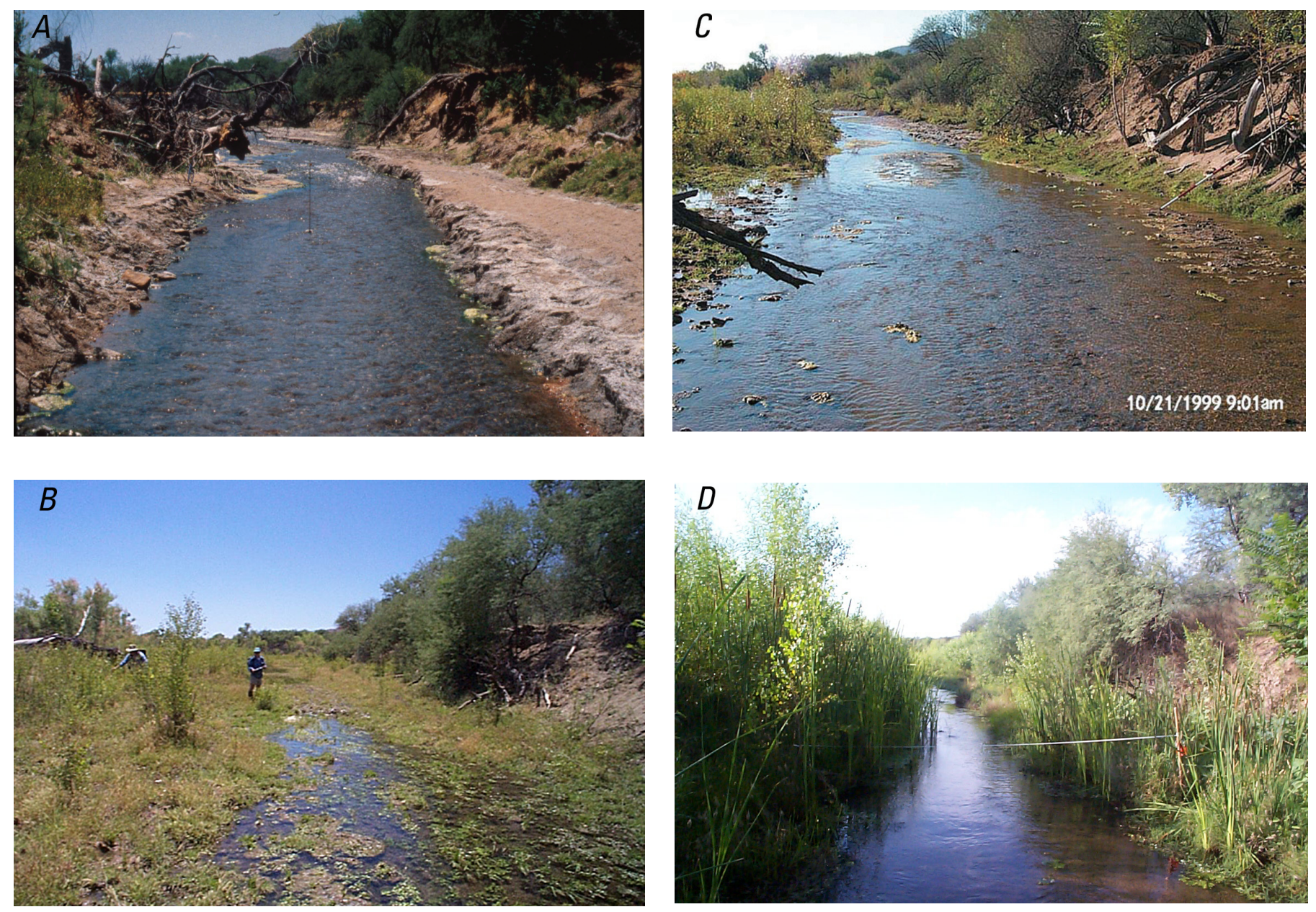

Figure 2-4. Pinal Creek, about 4.5 km upstream from the Pringle Pump Station near Globe, Ariz. (figs. 1-1, 1-2), showing patterns of growth and partial removal of vegetation since 1993. $A$, In 1995, little vegetation is present along stream as a result of $1993 \mathrm{flood}$ and subsequent smaller flow events. $B$, In August 1999, plant growth along banks has been reestablished, and significant algae and other aquatic plants are present in stream. $C$, In October 1999, vegetation in stream has been removed by summer monsoon-related storm runoffs, while vegetation along banks is largely unaffected. $D$. In August 2001, vegetation growth since treatment plant started has been significant. 
an introduction via Tucson Wash: Tucson, Arizona Geological Society Spring Field Trip Guidebook, 24 p.

Friehauf, K.C., 1996, Reaction paths of high-sulfidation-state copper-gold ore fluids in carbonate rocks — a case study at the Superior porphyry-related deposit, Arizona [abs.]: Geological Society of America Abstracts with Programs, v. 28, no. 7, p. A403.

Friehauf, K.C., and Pareja, G.A., 1998, Can oxygen isotope halos be produced around high-temperature dolostonehosted ore deposits?; evidence from the Superior District, Arizona: Economic Geology, v. 93, no. 5, p. 639-650.

Gustafson, L.B., 1961, Paragenesis and hypogene zoning at the Magma mine, Superior, Arizona: Cambridge, Mass., Harvard University, Ph.D. thesis, 93 p.

Hammer, D.F., and Peterson, D.W., 1968, Geology of the Magma mine area, Arizona, in Ridge, J.D., ed., Ore deposits of the United States, 1933-1967 (Graton-Sales volume): New York, American Institute of Mining, Metallurgical, and Petroleum Engineers, v. 2, p. 1282-1310.

Howard, K.A., 1991, Intrusion of horizontal dikes; tectonic significance of middle Proterozoic diabase sheets widespread in the upper crust of the southwestern United States: Journal of Geophysical Research, v. 96, no. B7, p. 12461-12478.

Howard, K.A., and Foster, D.A., 1996, Thermal and unroofing history of a thick, tilted Basin-and-Range crustal section in the Tortilla Mountains, Arizona: Journal of Geophysical Research, v. 101, no. B1, p. 511-522.

Kamilli, R.J., 1997, Fluid inclusion studies of the Mammoth deposit, Arizona, in Force, E.R., Geology and mineral resources of the Santa Catalina Mountains, southeastern Arizona, with sections by Daniel M. Unruh and Robert Kamilli (Monographs in Mineral Resource Science, no. 1): Tucson, University of Arizona Press, p. 101-106.

Kay, J.T., Conklin, M.H., Fuller, C.C., and O'Day, P.A., 2001, Processes of nickel and cobalt uptake by a manganese oxide forming sediment in Pinal Creek, Globe Mining District, Arizona: Environmental Science and Technology, v. 35, no. 24, p. 4719-4725.

Krieger, M.H., 1974, Geologic map of the Crozier Peak quadrangle, Pinal County, Arizona: U.S. Geological Survey Quadrangle Map GQ-1107, 11 p., scale 1:24,000.

Krieger, M.H., 1977, Large landslides, composed of megabreccia, interbedded in Miocene basin deposits, southeastern Arizona: U.S. Geological Survey Professional Paper $1008,25 \mathrm{p}$.

Lang, J.R., 1991, Isotopic and geochemical characteristics of geochemical characteristics of Laramide igneous rocks in
Arizona: Tucson, University of Arizona, Ph.D. thesis, 201 p.

Li, T.M., and Carter, R., 1975, Pinto Valley copper mineblueprint for insured productivity: Mining Engineering, v. 27 , no. 6, p. 25-32.

Lind, C.J., and Hem, J.D., 1993, Manganese minerals and associated fine particulates in the streambed of Pinal Creek, Arizona-a mining-related acid drainage problem: Applied Geochemistry, v. 8, no. 1, p. 67-80.

Lowell, J.D., 1968, Geology of the Kalamazoo orebody, San Manuel District, Arizona: Economic Geology, v. 63, no. 6, p. 645-654.

Lowell, J.D., and Guilbert, J.M., 1970, Lateral and vertical alteration-mineralization zoning in porphyry ore deposits: Economic Geology, v. 65, no. 4, p. 373-408.

Manske, S.L., and Paul, A.H., 2002, Geology of a major new porphyry copper center in the Superior (Pioneer) District, Arizona: Economic Geology, v. 97, no. 2, p. 197-220.

Munchmeyer, Carlos, 1996, Exotic deposits—products of lateral migration of supergene solutions from porphyry copper deposits, in Camus, Francisco, Sillitoe, R.H., and Peterson, Richard, eds., Andean copper deposits; new discoveries, mineralization, styles and metallogeny: Society of Economic Geology Special Publication 5, p. 43-58.

Naruk, S.J., Bykerk-Kauffman, Ann, Currier-Lewis, Debra, Davis, G.H., Faulds, J.E., and Lewis, S.W., 1986, Kink folding in an extended terrane; Tortilla Mountains, southeastern Arizona: Geology, v. 14, no. 12, p. 1012-1015.

Parsons, A.B., 1957, San Manuel, in The porphyry coppers in 1956: New York, American Institute of Mining, Metallurgical, and Petroleum Engineers, p. 244-256.

Paul, A.H., and Knight, M.J., 1995, Replacement ores in the Magma mine, Superior, Arizona, in Pierce, F.W., and Bolm, J.G., eds., Porphyry copper deposits of the America Cordillera: Arizona Geological Society Digest, v. 20, p. 366-372.

Peterson, N.P., 1938, Geology and ore deposits of the Mammoth mining camp area, Pinal County, Arizona: Arizona Bureau of Mines Bulletin 144, 63 p.

Peterson, N.P., 1962, Geology and ore deposits of the GlobeMiami district, Arizona: U.S. Geological Survey Professional Paper 342, $151 \mathrm{p}$.

Peterson, N.P., Gilbert, C.M., and Quick, G.L., 1946, Hydrothermal alteration in the Castle Dome copper deposit, Arizona: Economic Geology, v. 41, no. 8, p. 820-841.

Peterson, N.P., Gilbert, C.M., and Quick, G.L., 1951, Geology and ore deposits of the Castle Dome area, Gila County, Arizona: U.S. Geological Survey Bulletin 971, 134 p.

Phillips, C.H., Cornwall, R.H., and Rubin, Meyer, 1971, A Holocene ore body of copper oxides and carbonates at Ray, 
Arizona: Economic Geology, v. 66, no. 3, p. 495-498.

Phillips, C.H., 1976, Geology and exotic copper mineralization in the vicinity of Copper Butte, Pinal County, Arizona, in Woodward, L.S., and Northrop, S.A., eds., Tectonics and mineral resources of southwestern North America (Kelly volume): New Mexico Geological Society Special Publication 6, p. 174-179.

Ransome, F.L., 1903, Geology of the Globe copper district, Arizona: U.S. Geological Survey Professional Paper 12, 168 p.

Richard, S.M., and Spencer, J.E., 1998, Compilation geologic map of the Ray-Superior area, central Arizona: Arizona Geological Survey Open-File Report 98-13, 47 p., scale $1: 24,000$

Schmidt, E.A., 1971, A structural investigation of the northern Tortilla Mountains, Pinal County, Arizona: Tucson, University of Arizona, Ph.D. thesis, 248 p.

Sell, J.D., 1995, Discovery of a deep (3500 feet) unexposed porphyry copper deposit at Superior East, Pinal County,
Arizona, in Pierce, F.W., and Bolm, J.G., eds., Porphyry copper deposits of the American Cordillera: Arizona Geological Society Digest, v. 20, p. 373-395.

Short, M.N., Galbraith, F.W., Harshman, E.N., Kuhn, T.H., and Wilson, E.D., 1943, Geology and ore deposits of the Superior mining area, Arizona: Arizona Bureau of Mines and Geology, Bulletin 151, 159 p.

Steele, H.J., and Rubly, G.R., 1948, San Manuel prospect [Arizona]: American Institute of Mining and Metallurgical Engineers Transactions, v. 178, p. 181-194.

Timmers, J., 1986, Response to finding of violation and order IX-FY86-78: Inspiration Consolidated Copper Co. letter to U.S. Environmental Protection Agency, Water Management Division, August 27, 1986, 44 p.

Wilkins, Joe, Jr., and Heidrick, T.L., 1995, Post-Laramide extension and rotation of porphyry copper deposits, southwestern United States, in Pierce, F.W., and Bolm, J.G., eds., Porphyry copper deposits of the American Cordillera: Arizona Geological Digest, v. 20, p. 109-127. 

Appendixes 1-2 


\section{Appendix 1.}

\section{Mine Fact Sheets}

\author{
By Keith R. Long
}

\section{San Manuel Mine, Concentrator, and Smelter}

\section{Location}

Underground mine is about $13 \mathrm{~km} \mathrm{NE}$. of Oracle, Ariz., at lat $32^{\circ} 41^{\prime} 46^{\prime \prime}$ N., long $110^{\circ} 41^{\prime} 21^{\prime \prime}$ W., in sec. 34 , T. 8

S., R. 16 E. Concentrator is about $16 \mathrm{~km} \mathrm{E.} \mathrm{of} \mathrm{Oracle} \mathrm{at} \mathrm{lat}$ $32^{\circ} 36^{\prime} 38^{\prime \prime} \mathrm{N}$., long $110^{\circ} 37^{\prime} 16^{\prime \prime} \mathrm{W}$. in the $\mathrm{SE}^{1 / 4 \mathrm{NE}^{1} / 4} \mathrm{sec}$. 32, T. 9 S., R. 17 E., and smelter is nearby at lat $32^{\circ} 36^{\prime} 58^{\prime \prime}$ N., long $110^{\circ} 37^{\prime} 18^{\prime \prime} \mathrm{W}$. in the $\mathrm{S}^{1 / 2} \mathrm{SE}^{1 / 1} / 4$ sec. 29 , T. 9 S., R. 17 E.

\section{Ownership}

BHP Billiton Base Metals, a division of BHP Billiton.

\section{Production}

\section{San Manuel and Kalamazoo Underground Mine (Magma Copper Co.)}

From 1955 to 1998,693 million tons of ore containing 0.67 weight percent $\mathrm{Cu}$ was milled, from which 1.63 million tons $\mathrm{Cu}, 15$ million troy oz $\mathrm{Ag}, 0.7$ million troy oz $\mathrm{Au}$, and 140 million $\mathrm{lb}$ Mo was recovered in concentrate. Inplace leaching from 1986 to 1998 yielded 123,439 tons of cathode copper.

\section{San Manuel Open-Pit Mine}

From 1986 to 1994,144 million tons of waste was removed, and 92 million tons of ore containing 0.35 weight percent $\mathrm{Cu}$ was placed on the leach pad. Leaching from 1986 to 1998 including production from heap leaching, well-to-well leaching, and well-to-underground-sump leaching, yielded 339,288 tons of cathode copper.

\section{Reserves and Resources}

\section{San Manuel-Kalamazoo Mine}

Reserves in all categories in 1997 were 562 million tons of ore containing 0.61 weight percent $\mathrm{Cu}$.

\section{Chronology}

[USBM, U.S. Bureau of Mines; USGS, U.S. Geological Survey. SX/EW, solvent extraction and electrowinning.]

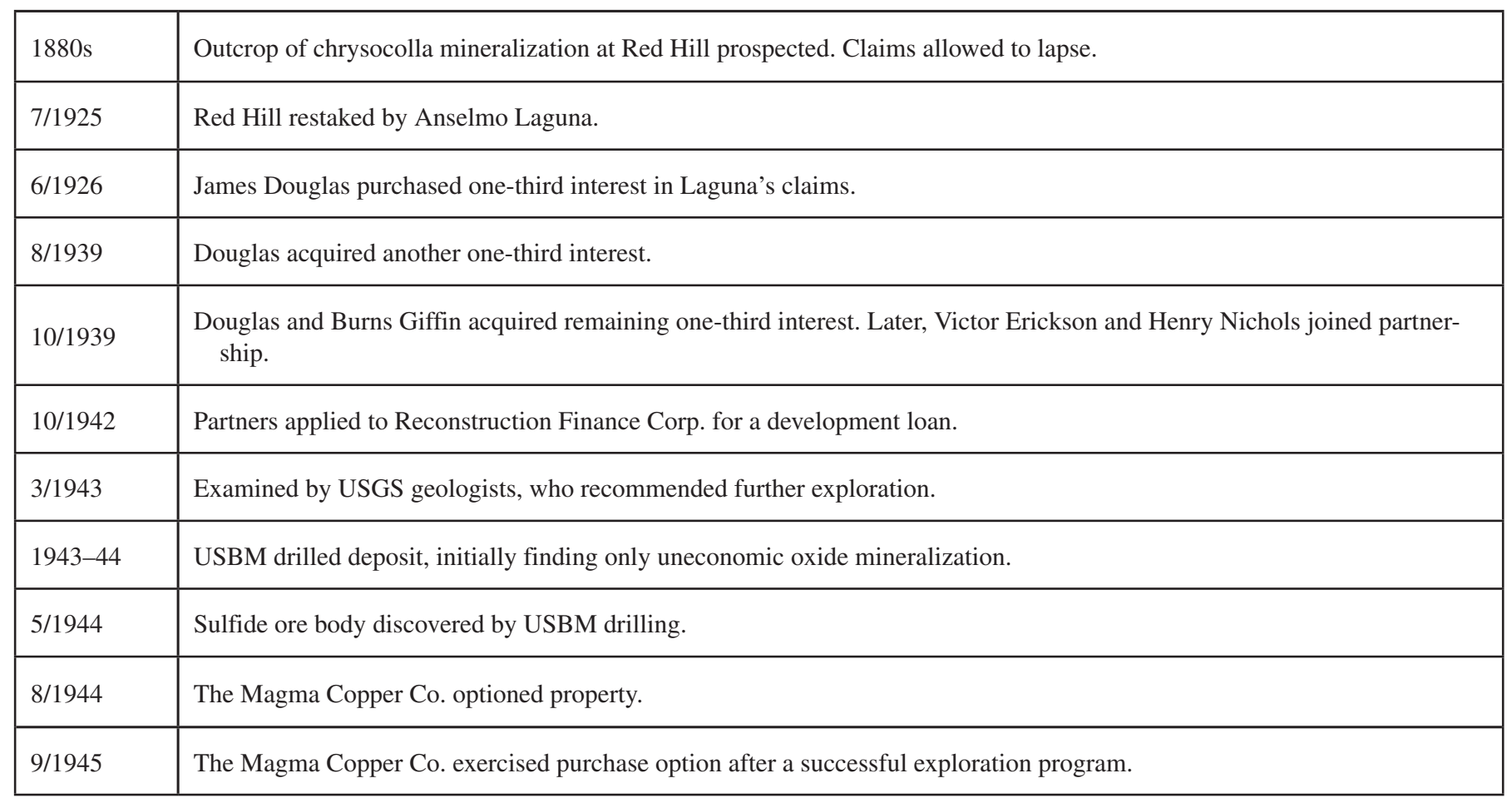




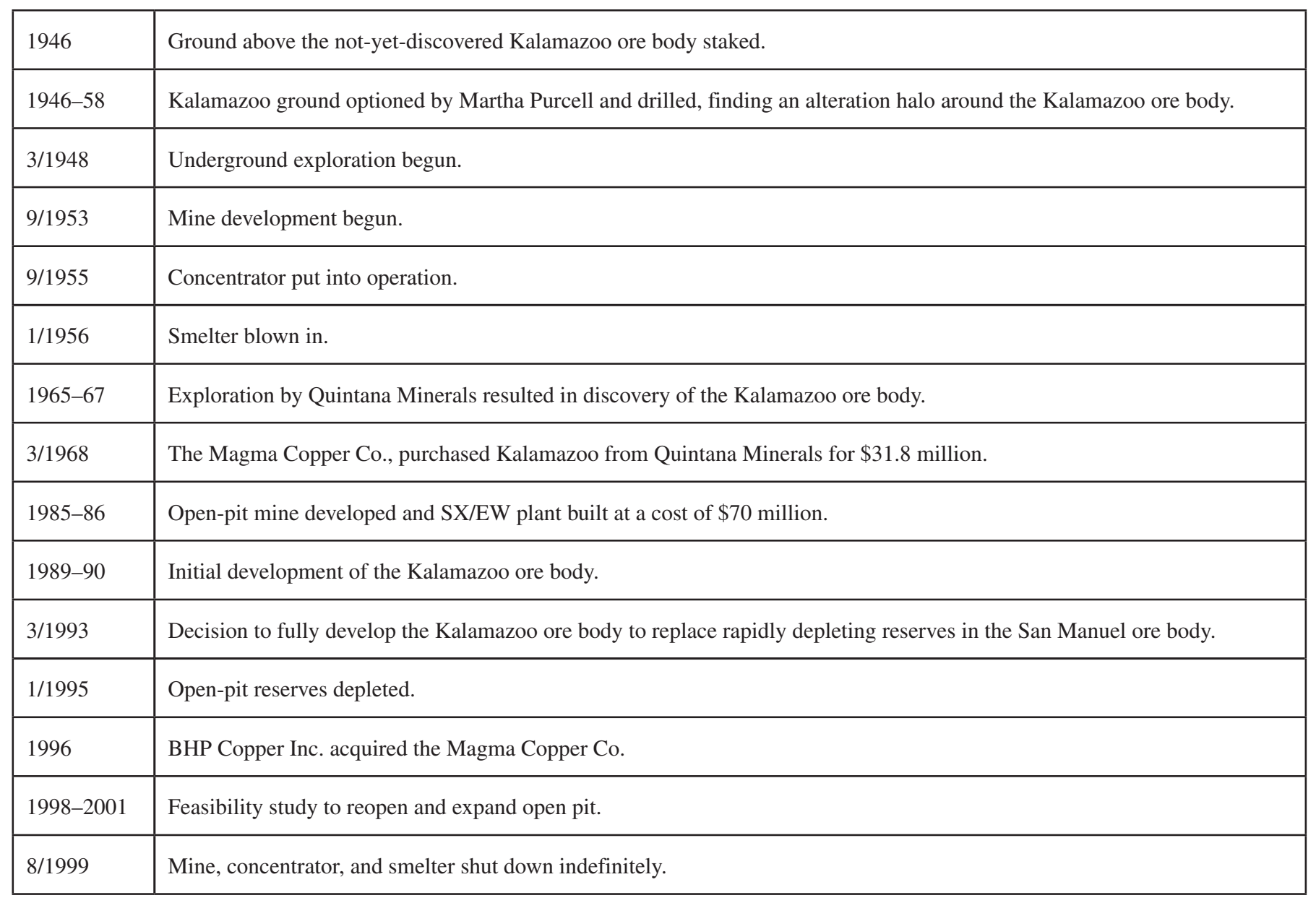

\section{Geology}

\section{Host Rock}

Precambrian Oracle Granite (quartz monzonite) and diabase intruded by dike swarms and irregular masses of early Paleocene (67-69 Ma) San Manuel Porphyry (biotite-dacite porphyry, granodiorite porphyry).

\section{Overburden}

Conglomerate of the upper Oligocene to lower Miocene Cloudburst Formation conglomerate and the lower Miocene San Manuel Formation, with fluvial sedimentary rocks of the conglomerate, mid-Miocene to Pliocene Quiburis Formation.

\section{Age of Mineralization}

Paleocene.

\section{Original Configuration}

A single annular tablocylindroidal ore body around a $\mathrm{N}$. $81^{\circ}$ E., $62^{\circ}$ SE.-aligned dike.

\section{Current Configuration}

Original deposit dismembered by Tertiary extensional faulting into two ore bodies, the San Manuel and the deeper Kalamazoo.

\section{Primary Mineralization}

Pyrite, chalcopyrite, and molybdenite in veinlets, disseminated blebs, and fracture coatings. Total sulfide content, 2 to 4 weight percent; pyrite to chalcopyrite ratio, $1: 1$ to $1: 3$.

\section{Alteration}

Potassic: quartz-K-feldspar-bearing veinlets, some accompanied by biotite veinlets; phyllic: quartz-sericite-sulfide-bearing veinlets; propylitic: pervasive chloritization and epidotization.

\section{Weathering and Supergene Enrichment}

Small part of deposit exposed and altered by supergene processes. Mineralogy consists of chrysocolla and copper wad, with minor cuprite, malachite, and traces of native copper. Local bodies of chalcocite. 


\section{Ray Mine and Mill}

\section{Location}

Open-pit mine is about $15 \mathrm{~km} \mathrm{SE}$. of Superior, Ariz., at lat $33^{\circ} 11^{\prime} 00^{\prime \prime} \mathrm{N}$., long $111^{\circ} 00^{\prime} 00^{\prime \prime} \mathrm{W}$., in secs. $10-15$, 23, and 24, T. 3 S., R. 13 E. Concentrators are south of the mine at lat $33^{\circ} 05^{\prime} 54^{\prime \prime}$ N., long $110^{\circ} 55^{\prime} 22^{\prime \prime}$ W., in sec. 9, T. 4 S., R. 13 E., and near Hayden, Ariz., $32 \mathrm{~km}$ from the mine at lat $33^{\circ} 00^{\prime} 19^{\prime \prime}$ N., long $110^{\circ} 46^{\prime} 55^{\prime \prime}$ W., in sec. 11 , T. 5 S., R. 15 E.

\section{Ownership}

Asarco, Inc., a wholly owned subsidiary of Grupo México.

\section{Production}

\section{Ray Underground Mine}

From 1911 to 1954,79 million tons of ore containing 1.46 weight percent $\mathrm{Cu}, 0.030$ troy oz $\mathrm{Ag} / \mathrm{ton}$, and 0.0004 troy oz Au/ton was milled, and another 0.5 million tons of ore containing 2.29 weight percent $\mathrm{Cu}$ was shipped directly to the smelter.

\section{Ray Open-Pit Mine}

From 1950 to 1998, 494 million tons of ore containing 0.88 weight percent $\mathrm{Cu}$ was milled. Concentrates recovered contained 3.4 million tons $\mathrm{Cu}$, as well as $\mathrm{Au}, \mathrm{Ag}$, and $\mathrm{Mo}$. From 1964 to 1987, 288,722 tons $\mathrm{Cu}$ was recovered in copper precipitates; from 1985 to $1998,476,722$ tons of cathode copper was recovered by the SX/EW plant.

\section{Reserves and Resources}

\section{Ray Mine}

Reserves in all categories in 1998 were 1.129 billion short tons of ore containing 0.58 weight percent $\mathrm{Cu}$.

\section{Chronology}

[SX/EW, solvent extraction and electrowinning]

\begin{tabular}{|c|c|}
\hline 1846 & U.S. Army troops discovered chrysocolla cropping out in a place they named "Mineral Creek." \\
\hline 1870 & First mining claim, the Ray Lode, located. \\
\hline 1880 & The Mineral Creek Mining Co. built a five-stamp mill, which operated unsuccessfully for a short while. \\
\hline 1883 & The Ray Copper Co. \\
\hline 1898 & The Globe Mines Exploration Co., Ltd. \\
\hline $1899-1901$ & $\begin{array}{l}\text { Ray Copper Mines Ltd. acquired claims of the L. Zeckendorf \& Co. and developed an underground mine connected to a } \\
\text { 300-ton/day-capacity concentrator built at Kelvin near a narrow-gauge railroad at a cost of } \$ 0.5 \text { million. }\end{array}$ \\
\hline $1906-7$ & D.C. Jackling and others acquired control of the property and organized the Ray Consolidated Copper Co. \\
\hline $1907-10$ & Property explored delineating an 80-million-ton reserve of ore containing 2.17 weight percent $\mathrm{Cu}$. \\
\hline $3 / 1911$ & $\begin{array}{l}\text { Underground mine put into production, using shrinkage stopping and block caving. Hayden mill started at 10,000-ton/ } \\
\text { day capacity. }\end{array}$ \\
\hline 1912 & $\begin{array}{l}\text { Asarco, Inc., completed the Hayden smelter with a long-term contract to treat Ray concentrates. Acquired property of } \\
\text { the Ray Central Copper Mining Co. }\end{array}$ \\
\hline 1926 & The Nevada Consolidated Copper Co. acquired the property through merger with the Ray Consolidated Copper Co. \\
\hline
\end{tabular}




\begin{tabular}{|c|c|}
\hline 1927 & The Nevada Consolidated Copper Co. completed consolidation of all properties in the district. \\
\hline 1933 & Kennecott Copper Corp. acquired the Ray Mine through its merger with the Nevada Consolidated Copper Co. \\
\hline $1 / 1937$ & Inplace leaching of worked-out areas of underground mine begun. \\
\hline $1948-55$ & Underground mining operations gradually replaced by open-pit mining. \\
\hline 1952 & Hayden mill expanded to 12,000 -ton/day capacity. \\
\hline $2 / 1957$ & Leach-precipitation-flotation circuit added at the Hayden concentrator completed at a cost of $\$ 5$ million. \\
\hline 1958 & New 240-ton/day-capacity anode copper smelter commissioned. \\
\hline $1958-61$ & Hayden mill expanded to 22,500-ton/day capacity. Total cost of improvements, including smelter, was $\$ 40$ million. \\
\hline 1966 & Molybdenum recovery circuit added to the Hayden mill. \\
\hline 1968 & Second reverberatory furnace installed at the Hayden smelter at a cost of $\$ 12$ million. \\
\hline 1969 & Silicate vat leaching and 10,000-ton/yr-capacity copper SX/EW plant installed at a cost of $\$ 47$ million. \\
\hline $1973-76$ & SX/EW facility expanded to 14,000 -ton- $\mathrm{Cu} / \mathrm{yr}$ capacity at a cost of $\$ 7$ million. \\
\hline 1977 & Hayden mill expanded to 29,000 -ton/day capacity. \\
\hline 1981 & Capacity of SX/EW plant expanded at a cost of $\$ 19$ million. \\
\hline $5 / 1982$ & Operations suspended because of low copper price. Ray smelter mothballed. \\
\hline $9 / 1983$ & Operations resumed. Inco oxygen flash furnace installed at the Hayden smelter at a cost of \$132 million. \\
\hline $11 / 1986$ & $\begin{array}{l}\text { Property sold to Asarco, Inc., for } \$ 72 \text { million cash plus a royalty related to the price of copper over a } 10 \text {-year period end- } \\
\text { ing } 1 / 1999 \text {, capped at } \$ 65 \text { million. }\end{array}$ \\
\hline $1986-87$ & $\begin{array}{l}\text { Sulfide-waste-dump leach solutions redirected to SX/EW plant, and precipitation plant decommissioned. SX/EW plant } \\
\text { expanded to } 40,000 \text {-ton- } \mathrm{Cu} / \mathrm{yr} \text { capacity at a cost of } \$ 1.1 \text { million. }\end{array}$ \\
\hline 1988-89 & $\begin{array}{l}\text { Hayden mill expanded to 30,000-ton/day capacity at a cost of \$12 million. Slag-cleaning furnace built at the Hayden } \\
\text { smelter at a cost of } \$ 20 \text { million. }\end{array}$ \\
\hline $2 / 1992$ & $\begin{array}{l}\text { Ray concentrator begins operation, bringing total capacity, including Hayden concentrator, to } 60,000 \text { tons/day. Cost of } \\
\text { new mill, a 60,000-ton/day-capacity inpit crusher, and overall mine expansion was } \$ 240 \text { million. }\end{array}$ \\
\hline 1995 & $\begin{array}{l}\text { Asarco, Inc., applied for a land exchange with the Bureau of Land Management to acquire } 4,720 \text { acres of additional land } \\
\text { and 1,818 acres of mineral rights adjacent to the Ray Mine. }\end{array}$ \\
\hline 1994-96 & Development program and modernization of the Hayden concentrator cost $\$ 10$ million. \\
\hline 1998 & Ferric cure leaching begun. \\
\hline 1999 & Ray secondary crusher commissioned; tankhouse renovation completed. \\
\hline
\end{tabular}




\section{Geology}

\section{Host Rock}

Precambrian Pinal Schist, Ruin Granite, sedimentary rocks of the Apache Group, and diabase intruded by dikes, sills, and chonolithic masses of early Paleocene (61 Ma) Granite Mountain Porphyry. About 20 percent of the mineralization is in Granite Mountain Porphyry, and the rest in Precambrian rocks.

\section{Overburden}

White Tail Conglomerate, Miocene dacitic welded tuff, Gila Conglomerate, and rhyolite tuff. Capping on original 1911 ore body was $96 \mathrm{~m}$ thick, with irregular stringers of native copper.

\section{Age of Mineralization}

Paleocene (65 Ma).

\section{Original Configuration}

A much larger deposit.

\section{Current Configuration}

Substantial part of the deposit eroded into Tertiary sedimentary basin to the west.

\section{Primary Mineralization}

Pyrite, chalcopyrite, molybdenite, local minor bornite, and trace sphalerite, galena, and tennantite. Primary mineralization contains 0.1 to 0.2 weight percent $\mathrm{Cu}$ except in diabase, which contains more than 0.4 weight percent $\mathrm{Cu}$.

\section{Weathering and Supergene Enrichment}

Much of deposit was eroded and weathered, producing an oxidized zone of chrysocolla, native copper, cuprite, chalcotrichite, and native silver and an irregular enriched blanket, as much as hundred meters thick, of chalcocite and minor covellite.

\section{Pinto Valley Mine and Mill}

\section{Location}

Open-pit mine is about $8 \mathrm{~km} \mathrm{~W}$. of Miami, Ariz., at lat $33^{\circ} 25^{\prime} 01^{\prime \prime}$ N., long $110^{\circ} 56^{\prime} 00^{\prime \prime}$ W., in sec. 21 , T. 1 N., R. 14 E. Mill is south of the mine at lat $33^{\circ} 24^{\prime} 04^{\prime \prime} \mathrm{N}$., long $110^{\circ} 53^{\prime} 55^{\prime \prime}$ W., in sec. 25, T. 1 N., R. 14 E. The portal of the Castle Dome underground mine is at lat $33^{\circ} 23^{\prime} 28^{\prime \prime} \mathrm{N}$., long $110^{\circ} 57^{\prime} 18^{\prime \prime} \mathrm{W}$., in the $\mathrm{S}^{1} / 2$ sec. 20 , T. 1 N., R. 14 E.

\section{Ownership}

BHP Billiton Base Metals, a division of BHP Billiton.

\section{Production}

\section{Continental Mine (Lessees from the Old Dominion Mining Co.)}

From 1906 to 1941, 34,000 tons of hand-sorted ore was shipped to smelters, yielding 1,000 tons $\mathrm{Cu}, 134,000$ troy oz $\mathrm{Ag}$, and 3,600 troy oz Au.

\section{Castle Dome Mine (Miami Copper Co.)}

From June 1943 to December 1953, 41 million tons of ore containing 0.725 weight percent $\mathrm{Cu}, 0.0273$ troy oz $\mathrm{Ag} /$ ton, and 0.000535 troy oz Au/ton was milled. Some 257,125 tons $\mathrm{Cu}, 554,138$ troy oz $\mathrm{Ag}$, and 8,291 troy oz Au was recovered in concentrate. Dump leaching from 1954 to 1970 yielded 32,771 tons $\mathrm{Cu}$ in precipitates.

\section{Pinto Valley Mine}

From 1972 to 1998, 653 million tons of waste was removed, and 439 million tons of ore containing 0.42 weight percent $\mathrm{Cu}$ was milled. Concentrates recovered contained 1.6 million tons $\mathrm{Cu}$, as well as Au, Ag, and Mo. About 56 million tons of overburden was stripped before commercial mining. Dump leaching from 1981 to 1998 recovered 150,000 tons of cathode copper. 


\section{Chronology}

[SX/EW, solvent extraction and electrowinning]

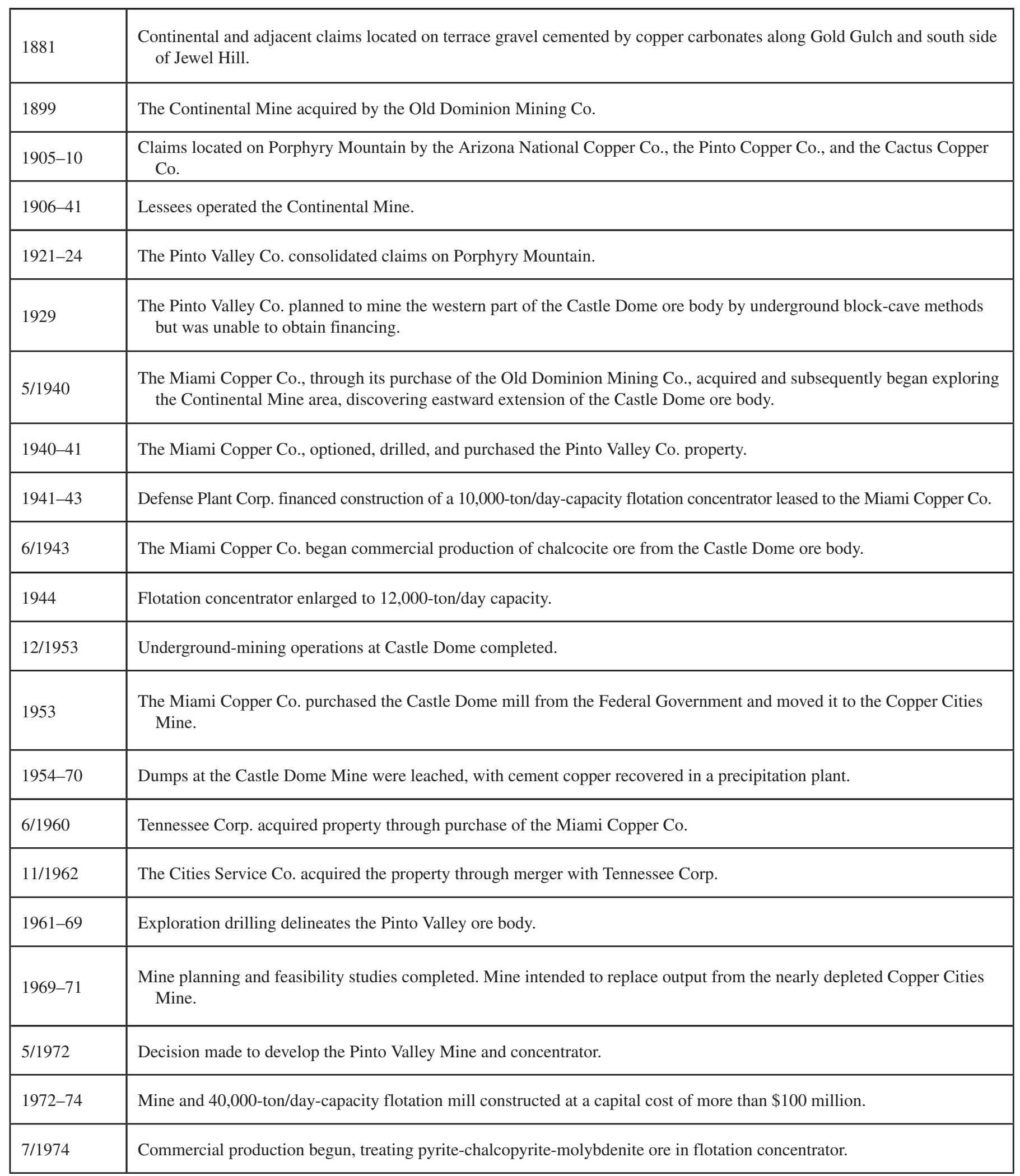




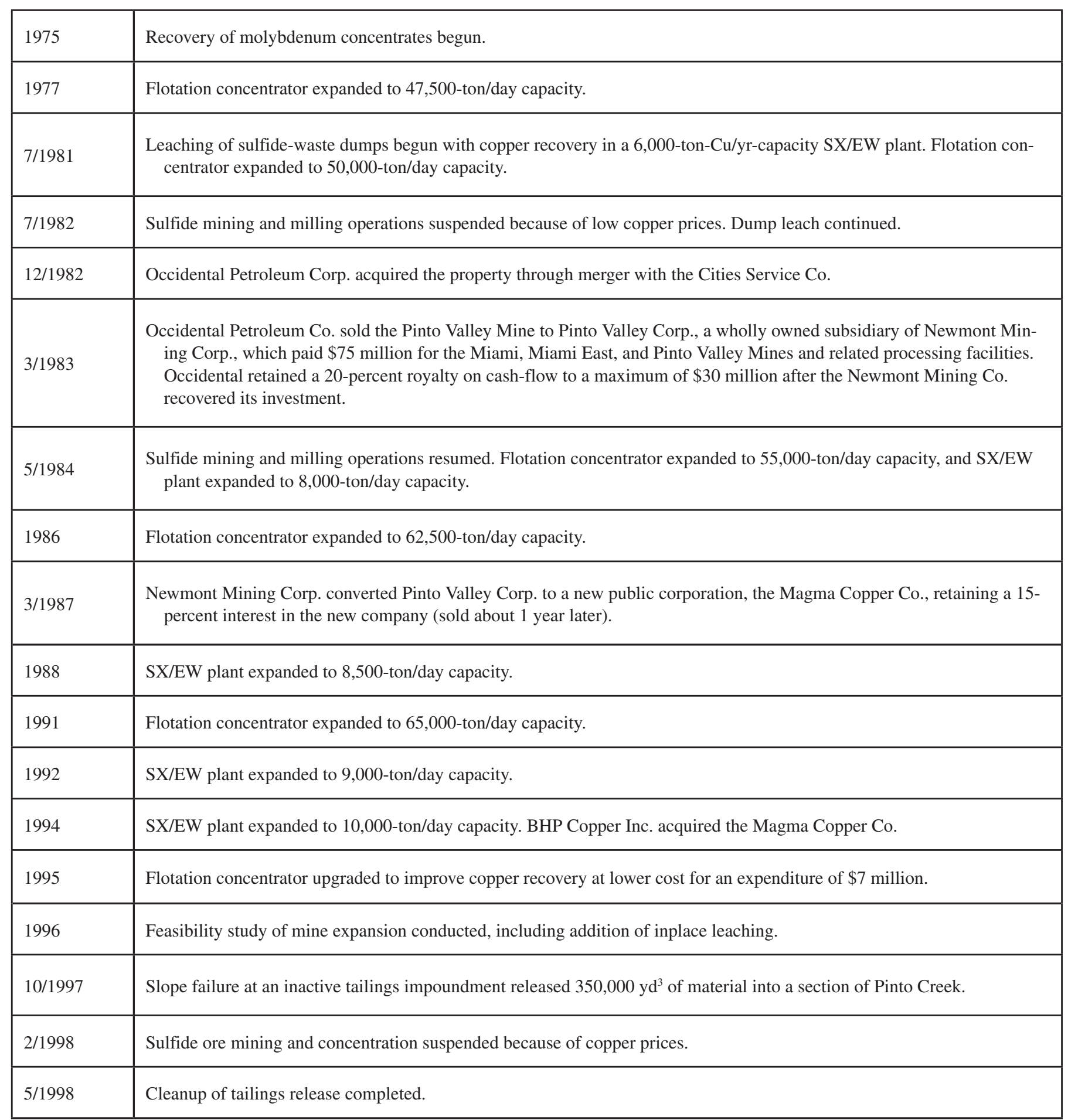




\section{Reserves and Resources}

\section{Pinto Valley Mine}

Reserves in all categories in 1997 were 631 million tons of ore containing 0.18 weight percent $\mathrm{Cu}$.

\section{Geology}

\section{Host Rock}

Precambrian Lost Gulch Quartz Monzonite intruded by small bodies and dikes of granite porphyry and granodiorite during the Paleocene (62 Ma). Minor diabase and Pinal Schist.

\section{Overburden}

About $150 \mathrm{~m}$ of Gila and White Tail Conglomerates.

\section{Age of Mineralization}

Paleocene (59.1 Ma).

\section{Original Configuration}

A distorted, inverted bowl with long axis striking about N. $80^{\circ}$ E., with an ore shell surrounding a low-grade core.

\section{Current Configuration}

Bounded by postmineral faults.

\section{Primary Mineralization}

Pyrite, chalcopyrite, and minor molybdenite occurring in veins and microfractures and less abundantly as disseminated crystals replacing biotite. The ore zone grades outward into a pyrite zone with a higher total sulfide content, and inward into a low-sulfide, low-grade core. Distribution of molybdenite generally follows that of chalcopyrite. Minor minerals include covellite, chalcocite, and sphalerite.

\section{Alteration}

Selectively pervasive argillic alteration characterized by replacement of plagioclase by montmorillonite. Veincontrolled phyllic alteration consisting of sericite selvages around quartz sulfide veins best is developed in the pyrite zone around and above the ore zone. Potassic alteration ranges from early, narrow zones of texture-destructive alteration to broad zones of hydrothermal biotite. Narrow zones of early texture-destructive sodic-potassic alteration, consisting of replacement of orthoclase and oligoclase by $\mathrm{K}$-feldspar and albite, restricted to the low-grade core.

\section{Weathering and Supergene Enrichment}

The Castle Dome ore body was a chalcocite-enrichment zone formed in the weathered upper part of part of the primary Pinto Valley ore body. 


\title{
Appendix 2. Abstracts for Evening Talks and Posters During the Field Trip
}

\section{Historical Life-Cycle Analysis of Southwestern Porphyry Copper Mining}

\author{
By Keith R. Long, U.S. Geological Survey
}

Economists analyze productivity by examining the contributions from various factors of production, such as capital, labor, natural resources, and technological innovation. All four factors are important to understanding the past, present, and future economic viability of porphyry copper mining in the Southwest. For individual mines, economic viability is limited by declining quantity and quality of the natural resource, copper ore, as the deposit is mined out. Existing mines are threatened by the discovery of higher-quality reserves elsewhere that can be mined at lower cost. To delay the inevitable, mining firms attempt to (1) substitute factors, such as capital for labor, to lower costs; (2) explore for equal- or better-quality reserves; and (3) invest in technology that will lower the cost of mining and convert resources into reserves. The first strategy, substitution of capital for labor, has been widely practiced in the mining industry during the 1900s. Whether substitution merely compensates for rising labor costs or has reduced costs overall is unknown. The second and third strategies are pursued to varying degrees at different times but may complement each other, such as a new technology that makes a previously ignored type of copper ore economically attractive.
To understand the future of porphyry copper mining in the Southwest, the past interplay between these factors of production and investment strategies needs to be understood. For a capital-intensive industry exploiting an immovable natural resource, investment alternatives in porphyry copper mining are significantly limited by sunk costs and past technological choices. Yet the industry has been rescued several times by the relatively rapid introduction of new extraction technology. This study uses dynamic mine and industry life-cycle models to document and analyze past and present industry performance, contributing to developing scenarios for the future of Southwest copper mining.

Over the past 150 years, economists have almost entirely ignored natural resources as a factor of production. Although technological innovation is widely studied, its role in making natural resources more productive is less so. This study makes contributions to natural-resource economics that go beyond mining. Other benefits are the identification of resources amenable to future technological innovation and a mine-by-mine record of historical and current material flows.

\section{Abundance and Behavior of Ore Metals in Latest Cretaceous through Early Tertiary ("Laramide") Metaluminous and Peraluminous Granitoids, South-Central Arizona and North-Central Sonora, Mexico}

\author{
By Gordon B. Haxel, U.S. Geological Survey
}

Two suites of latest Cretaceous to early Tertiary ("Laramide") granitoids are widespread in southern Arizona and northern Sonora: compositionally expanded calc-alkaline, fundamentally metaluminous granitoids, commonly associated with porphyry copper deposits; and compositionally restricted peraluminous leucogranites with no or few associated ore deposits. Approximately
80 samples of each of these two suites have been chemically analyzed to compare their concentrations of known and potential ore metals; samples were collected from 17 mountain ranges in south-central Arizona and north-central Sonora, Mexico, between Robles Junction, Ajo, Sonoyta, and Sáric. Nearly all of these carefully selected samples are unmineralized and minimally altered. 
Despite their association with porphyry copper deposits, Laramide metaluminous granitoids are unimpressive in their whole-rock $\mathrm{Cu}$ contents. During fractional crystallization of the metaluminous suite, copper behaves as a slightly or moderately compatible element $\left(D_{\mathrm{Cu}}=2.5 \pm 0.5\right)$.

At the high-silica end of their compositional range, Laramide metaluminous granitoids contain little or no more copper than the "control suite," peraluminous granites. The metaluminous suite as a whole does have higher $\mathrm{Cu}$ contents, but only because it is more mafic. However, the $\mathrm{Cu}$ contents even in intermediate metaluminous granitoids are unexceptional for rocks of their composition. Any special endowment in copper is subtle or, more likely, absent.

Laramide metaluminous granitoids also have unremarkable $\mathrm{Mo}, \mathrm{W}, \mathrm{Sn}, \mathrm{Nb}$, and Ta contents, and peraluminous leucogranites are notable for their low $\mathrm{Cu}, \mathrm{Mo}$, and $\mathrm{W}$ contents and modest enrichments in $\mathrm{Nb}$ and $\mathrm{Ta}$.

\title{
Evaluation and Application of the NURE Regional Geochemical Data for the Southwest: Nogales and Tucson $2^{\circ}$ Quadrangles, Southern Arizona
}

\author{
By Gordon B. Haxel, U.S. Geological Survey
}

In this poster, I report preliminary results from a study of the National Uranium Resource Evaluation (NURE) streamsediment database for the Southwest, emphasizing geochemical criteria for evaluating the data. The study area is centered on Arizona but also includes parts of adjacent southeastern California, southern Nevada, southern Utah, southwestern Colorado, and western New Mexico. The dataset comprises about 39,400 samples, from $312^{\circ}$-by- $1^{\circ}$ (1:250,000 scale) quadrangles.

In the Nogales and Tucson quadrangles, the NURE program analyzed approximately 2,960 samples of soil and stream sediment and obtained potentially useful data for 28 elements. At least 10 elements, with a wide range of geochemical properties, have median contents essentially the same as those of average upper continental crust: $\mathrm{Ba}, \mathrm{Ti}, \mathrm{V}, \mathrm{Mn}, \mathrm{Fe}, \mathrm{Zn}, \mathrm{La}$, $\mathrm{Ce}, \mathrm{Th}$, and B. Four strongly compatible elements ( $\mathrm{Sc}, \mathrm{Cr}, \mathrm{Co}$, and $\mathrm{Ni}$ ) are depleted relative to average upper continental crust, suggesting that the upper crust in this region is more highly evolved. Depletion in three high-field-strength elements ( $\mathrm{Zr}, \mathrm{Nb}$, $\mathrm{P})$ also is probably significant. Both $\mathrm{Cu}$ and $\mathrm{Pb}$ are slightly more abundant in the Nogales-Tucson area than in average upper continental crust. This difference is not simple to interpret, because the surface concentrations and distribution of $\mathrm{Cu}$ and $\mathrm{Pb}$ evidently have been affected by mining and other human activities. Regional $\mathrm{Th} / \mathrm{U}$ ratios range from 2.8 to 3.2 , significantly less than the global upper-crustal average of 3.8 .

One method for assessing data quality is to examine pairs of geochemically similar elements, such as $\mathrm{La}$ and $\mathrm{Ce}$. In the Nogales-Tucson area, La and Ce plot in a strongly linear array that includes approximately 95 percent of the data and closely brackets the upper-crustal $\mathrm{La} / \mathrm{Ce}$ ratio. A similar evaluation can be done by using other element pairs, such as $\mathrm{V}$ and Fe.

In the Nogales-Tucson area, major geochemical features of several elements as displayed on concentration-contour maps can be correlated with geologic terranes. 